\title{
Review
}

\section{Loss of Functional Alpha-Synuclein: A Toxic Event in Parkinson's Disease?}

\author{
Nicholas M. Kanaan and Fredric P. Manfredsson* \\ Department of Translational Science \& Molecular Medicine, College of Human Medicine, \\ Michigan State University, Grand Rapids, MI, USA
}

\begin{abstract}
The discovery that alpha-synuclein ( $\alpha$-syn) is the primary component of the neuropathological hallmarks of Parkinson's disease (PD) and the identification of $\alpha$-syn mutations in numerous inherited forms of PD has positioned $\alpha$-syn at the top of the list of important factors in the pathogenesis of PD. Based on the pathological accumulation of $\alpha$-syn in the brains of patients, the field is currently focused on therapeutic strategies that aim to reduce or eliminate $\alpha$-syn. However, recent evidence suggests $\alpha$-syn is a critical protein in neuron (i.e. dopamine neurons) survival and that maintaining a certain level of biologically functional $\alpha$-syn is an important consideration in targeting $\alpha$-syn for therapies. Despite the widespread interest in $\alpha$-syn, the normal biological functions remain elusive, but a large body of work is focused on addressing this issue. In this review, we will discuss the current evidence related to $\alpha$-syn function, $\alpha$-syn folding and aggregation, and $\alpha$-syn's role in disease. Finally, we will propose a relatively novel hypothesis on the pathogenesis of PD that hinges upon the premises that functional $\alpha$-syn is critical to cell survival and that a reduction in biologically functional $\alpha$-syn, whether through aggregation or reduced expression, may lead to the neurodegeneration in PD.
\end{abstract}

Keywords: Parkinson's disease, alpha-synuclein, neurodegenerative disease, dopamine, lewy body

\section{INTRODUCTION}

Numerous neurodegenerative diseases are characterized by the selective degeneration of specific neural populations, which typically exhibit accumulations of abnormally modified, misfolded and/or aggregated forms of amyloidogenic proteins. Among these proteins is prion protein in transmissible spongiform encephalopathies (i.e. Crutzfeld-Jacob's disease), amyloid- $\beta$ in Alzheimer's disease, tau protein in Alzheimer's disease and other tauopathies, huntingtin protein in Huntington's disease, and alpha-synuclein ( $\alpha$-syn) in Parkinson's disease (PD) and other synucleinopathies [1]. Typically, the presence of aggregated

${ }^{*}$ Correspondence to: Fredric P. Manfredsson, Department of Translational Science \& Molecular Medicine, College of Human Medicine, Michigan State University, 333 Bostwick Ave NE, Grand Rapids, MI 49503, USA. Tel.: +1 616234 0968; Fax: +1 616234 0990; E-mail: manfreds@msu.edu. (i.e. fibrillar, spherical, and/or oligomeric) forms of each protein in the somata and processes (i.e. axons and dendrites) of affected neurons represent the pathological hallmarks of these diseases and often constitute the definitive post-mortem diagnosis. Debates continue as to how the disease-related changes in these proteins directly play a role in the pathogenesis of disease. Here, we will review recent findings that may shed light on how disturbances in $\alpha$-syn can precipitate neuron dysfunction and death in the context of PD and other synucleinopathies.

$\alpha-S y n$

The synuclein family of proteins contains three known isoforms that includes $\alpha-, \beta$-, and $\gamma$-syn [2]. Alpha-synuclein was first cloned and isolated from the Pacific electric ray Torpedo californica in the pioneering work by Scheller and colleagues, who also 
demonstrated that $\alpha$-syn is primarily expressed in neural tissue and localized to the presynaptic terminals and nuclei (i.e. the nuclear envelope) of neurons in electric rays and rats [3]. The $\alpha$-syn gene (SNCA) is located in chromosome $4 \mathrm{q} 21.3-\mathrm{q} 22$ of humans [4] and encodes for a 140 amino acid protein. Although this is the primary isoform of $\alpha$-syn in neurons, alternative splicing at exons 3 and 5 can generate $\alpha$-syn 126 and 112 , respectively [5, 6]. The primary sequence of $\alpha$-syn is composed of 7 imperfect repeats of 11 residues that make up the highly basic amino-terminus (residues 1-60), a hydrophobic nonamyloid- $\beta$ component (NAC; residues 61-95), and an acidic C-terminal domain (residues 96-140). The SNCA gene is highly conserved across species with only a few amino acids differing between the human and rodent (i.e. mouse and rat) sequence $[2,7]$.

Alpha-synuclein is a highly soluble intrinsically disordered protein with virtually no tertiary structure and dynamic secondary structures as a monomer [8] (Fig. 1). Fitting with its disordered nature, $\alpha$-syn appears to exhibit a wide dynamic range of conformational states that varies with experimental conditions [9]. Multiple studies have confirmed the existence of long-range intramolecular interactions often involving the amino and carboxy termini $[10,11]$, but the precise regions of the proteins involved and whether these "global" conformations suppress [12,13] or enhance $[14,15]$ aggregation is not entirely clear. Some studies suggest that the interaction between the amino and carboxy termini creates a partially folded monomer that resists aggregation by blocking the amyloidogenic portions of the protein $[12,13]$. Another structural feature of $\alpha$-syn is the $\alpha$-helical content in the amino terminus. A large number of studies using spectroscopic techniques suggest two anti-parallel $\alpha$-helices connected by a short linking segment and/or a single extended helix form in $\alpha$-syn (Fig. 1B) that is significantly increased when it binds lipids [16-18]. There is little doubt that the amino terminal helices are critically important in $\alpha$-syn's interaction with membranes and this interaction is influenced by the chemical composition of the membrane, ionic strength of the solutions, vesicle curvature (i.e. size), and the mass ratio of $\alpha$ syn to lipids (reviewed in [19]). Thus, it seems likely that the both the intrinsic disorder of soluble $\alpha$-syn monomers and the amino terminal helices are important for $\alpha$-syn's biological interactions and functions [15].

Recently, the primary state of $\alpha$-syn under normal physiological conditions has come under debate. A set of recent studies have isolated $\alpha$-syn tetramers from human red blood cells demonstrating that $\alpha$-syn may exist as a tetramer under normal physiological conditions. Interestingly, the tetramers do not readily polymerize into fibrils [20] and $\alpha$-syn tetramers derived from recombinant $\alpha$-syn expressed in E. coli do not appear to be toxic to neurons in culture [21]. Moreover, disease-related mutant forms of $\alpha$-syn (i.e. A30P, A53T and E46K) appear to disrupt the formation/stability of tetramers [21]. These studies suggest that the tetramers are a "safe" form of $\alpha$-syn and might represent a means to store $\alpha$-syn in various subcellular compartments (i.e. the synapse or nucleus) prior to performing its biological functions.

The debate remains ongoing in light of a recent publication from a team of seven research groups that used extensive biochemical analyses of $\alpha$-syn (recombinant, endogenous and exogenously expressed $\alpha$-syn) derived from a long list of sources ranging from humans, rats, and mice to multiple cell types in culture [22]. These studies could not find evidence to support the existence of a tetrameric form of $\alpha$-syn under both non-denaturing and denaturing conditions [22]. Perhaps, $\alpha$-syn exists in a state of dynamic equilibrium between a disordered monomer and a tetrameric form, which may be facilitated by factors (still unknown) in situ (e.g. lipid interactions and/or chaperone interactions). While there has been substantial progress in understanding the dynamics of $\alpha$-syn protein structure, many questions remain unanswered. Exactly how does structure affect $\alpha$-syn function? What is the functional state of $\alpha$-syn? How is $\alpha$-syn structure affected in disease states? What is the structure of the toxic species of $\alpha$-syn?

\section{$\alpha$-Syn expression in the CNS}

During development in the CNS, the patterns of $\alpha$ syn expression appear to follow a stereotypical shift in distribution from the somata to the nerve terminals as development progresses. This holds true for nearly all brain regions analyzed in humans and rats, including the cortex, hippocampus, and substantia nigra, among others [23-25]. In fact, the expression of $\alpha$ syn appears at 15 weeks gestation in the cell body of human nigral neurons, which is 4 weeks after the appearance of tyrosine hydroxylase, and $\alpha$-syn is localized in the processes/nerve terminals by 18 weeks of gestation [26]. In a detailed analysis of $\alpha$-, $\beta$ - and $\gamma$-syn protein in the adult rats, $\mathrm{Li}$ and co-workers demonstrated wide-spread $\alpha$-syn reactivity throughout the CNS exclusively in nerve terminals/processes (no cell body reactivity was observed) [27]. Studies in mice 


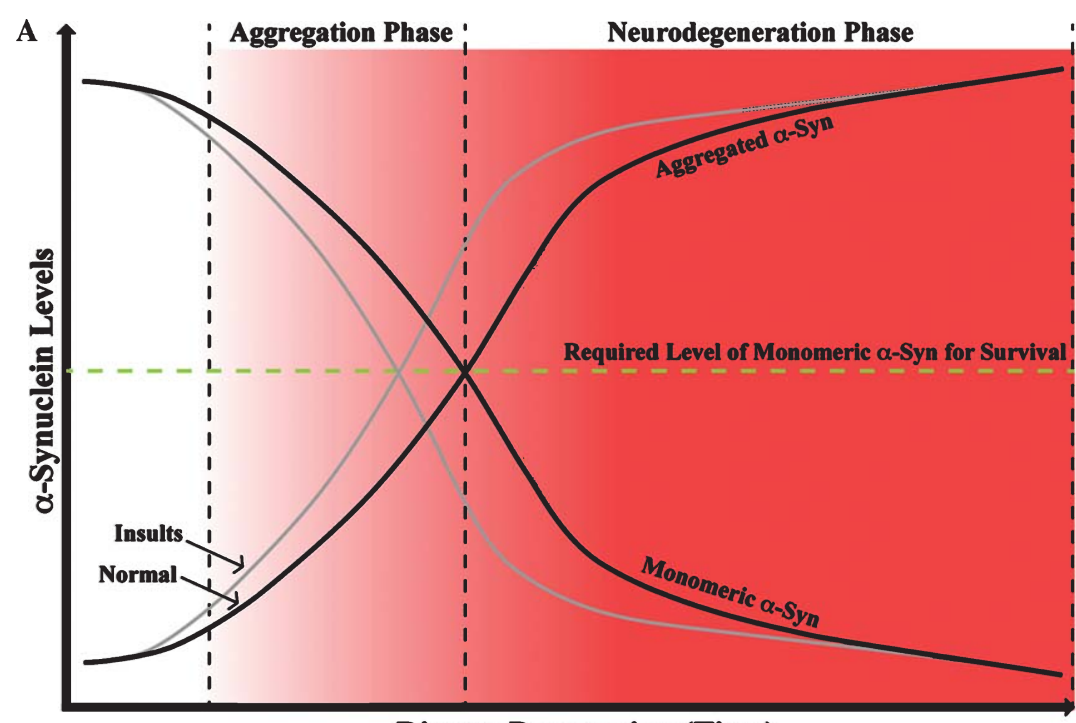

Disease Progression (Time)

${ }^{B}$

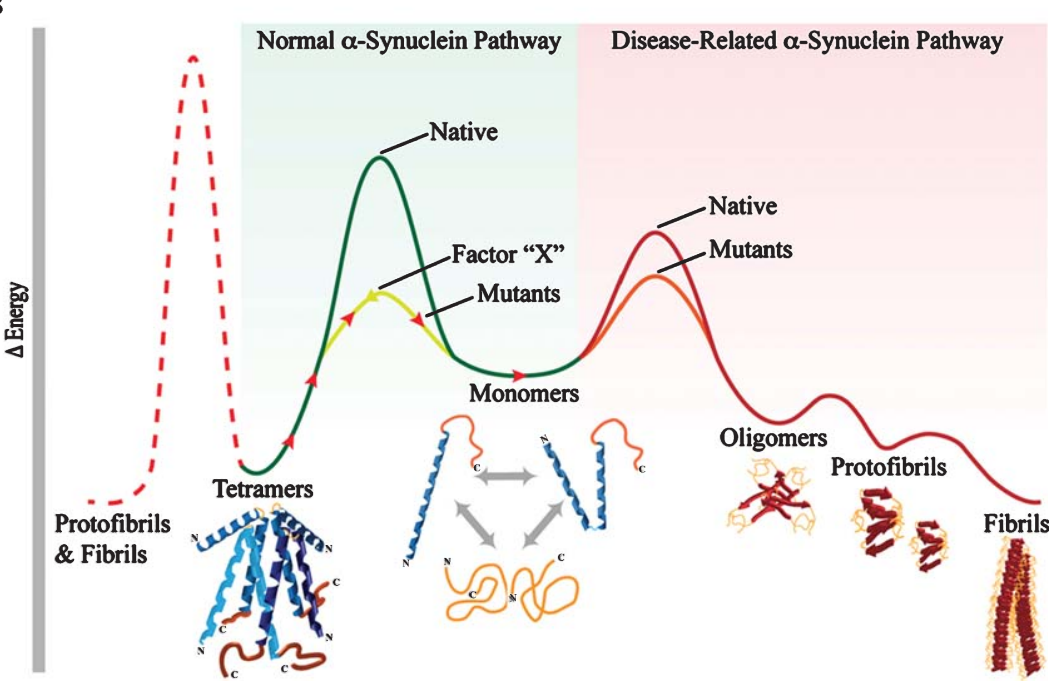

Fig. 1. Models of the role of $\alpha$-synuclein ( $\alpha$-syn) in Parkinson's disease (PD) and the folding/aggregation properties of $\alpha$-syn. (A) Alpha-syn is a critical player in the pathogenesis of PD and the loss-of-function hypothesis posits that as the disease progresses the pool of functional $\alpha$-syn is depleted via aggregation (in the aggregation phase). The neurons in which $\alpha$-syn is being reduced succumb to death once the pool of biologically functional $\alpha$-syn is depleted past a certain threshold (green dashed line). Numerous insults that are intrinsic (e.g. mutant $\alpha$-syn, abnormal $\alpha$-syn modifications, oxidative stress, etc.) or extrinsic (e.g. environmental toxins, neuroinflammation, etc.) to the neurons can augment the process quickening the progression of the disease (gray line). (B) The structure and aggregation profile of $\alpha$-syn is relatively complex. Under normal conditions, $\alpha$-syn exist as a disordered monomer or in a stable tetramer. Interestingly, the formation of tetramers in vitro is less favorable than the formation of aggregates (green line), but in vivo $\alpha$-syn may primarily exist in the tetrameric form (yellow-green line). This suggests two possibilities. 1) The in vitro conditions are not representative of in vivo conditions, and/or 2) there are unknown factors (Factor "X") that facilitate the formation of tetramers in vivo (e.g. chaperones). If tetramers are dissociated they are more likely to form aggregates (dashed red arrows) than they are to reform tetramers. Disease-associated mutations of $\alpha$-syn impede the formation of tetramers, and favor the formation of aggregates. The aggregation pathway is characterized by the progressive formation of soluble oligomers, protofibrils and mature fibrils (red line). Mutant forms of $\alpha$-syn reduce the energy barrier for the formation of oligomers; and thus, favor the formation of fibrils (orange line). One important caveat with these models is that they tend to simplify a complicated process and make some generalizations that do not fit all of the current data. With that in mind, it is important to view these models with the understanding that they can, and should, be modified as more data become available. 
have demonstrated that $\alpha$-syn expression is detected as early as embryonic day 9.5 in areas such as the hindbrain/midbrain junction [28] and its expression rises sharply in the following days indicating that the protein is important at certain stages of neuronal differentiation and development [29]. In addition, the differential distribution of $\alpha$-syn in development suggests $\alpha$-syn is expressed early in development and plays a role in maintaining nerve terminals in adulthood in numerous, but select cell populations.

On the other end of the developmental spectrum, normal aged brains exhibit a redistribution of $\alpha$-syn that is reminiscent of early development in the nigrostriatal system. In humans over 80 years old the level of $\alpha$-syn is doubled in the cell bodies of the substantia nigra compared to those less than 60 years old, and this effect appears relatively region-specific as no aging-related increases were seen in the frontal cortex or caudate nucleus [27]. Moreover, aging-related increases in $\alpha$-syn were exaggerated in neuromelanincontaining neurons of the substantia nigra [30], which are more susceptible to degeneration in PD and nonhuman models of PD [31, 32]. A similar pattern of somatodendritic accumulation of $\alpha$-syn was found in aged nigral DA neurons of non-human primates using immunohistochemical and densitometry measures [33]. Interestingly, transcriptional analyses of $\alpha$-syn mRNA expression typically indicate an aging-related reduction in $\alpha$-syn mRNA in numerous brain regions of humans, mice and rats, including the substantia nigra, striatum, cerebellum, hippocampus, and cortex [24, 34-36]. The aging-related increases in nigral neuron $\alpha$-syn levels may be limited to humans and non-human primates as studies in mice report decreased levels of $\alpha$-syn protein with advancing age [35].

Nonetheless, aging remains one of the strongest risk factors for developing PD [37], and thus, it is not entirely surprising that $\alpha$-syn undergoes some precursory changes to those seen in PD (i.e. accumulation in the cell body). Both nitrated and phosphorylated forms of $\alpha$-syn, which are prominent in PD-related $\alpha$-syn pathology [38, 39], are significantly elevated in aged monkey nigral neurons [40]. In addition, the redistribution of $\alpha$-syn from the terminals to the cell body may be indicative of neurons initiating maladaptive developmental plasticity-like signals [41], or age-related impairment of axonal transport of $\alpha$-syn $[42,43]$. Finally, the re-localization of $\alpha$-syn away from the synapse removes the protein from a cellular compartment where it performs crucial neuronal functions and may represent a primary mechanism of $\alpha$-syn loss-of-function in aging and disease (see below).

\section{Role of $\alpha$-Syn in disease}

Mutations in SNCA were the first identified genetic determinant of PD, causing a small subset of familial forms of the disease [44, 45]. Moreover, genetic overexpression via gene duplication or triplication was later shown to result in a form of inherited PD [46, 47]. Importantly, higher copy-numbers of $\alpha$-syn result in a more aggressive form of the disease suggesting a direct relationship between expression levels and disease severity [48]. Following the identification of disease-causing $\alpha$-syn mutations, the fibrilized form of the protein was identified as the major component of Lewy bodies, the hallmark cytoplasmic inclusions in sporadic forms of the disease [49]. More recently, polymorphisms of the $\alpha$-syn gene and the SCNA promoter have been implicated in sporadic PD [50]. Consequently, $\alpha$-syn is generally thought to play an important and potentially causative role in most, if not all, forms of PD.

\section{$\alpha$-Syn aggregation}

The direct mechanism(s) whereby perturbations of $\alpha$-syn results in toxicity and subsequent disease are unknown. However, it is commonly proposed that the self-assembly of $\alpha$-syn into soluble oligomers and/or insoluble aggregates that are directly toxic underlie its role in disease [51]. Due to the fact that the precise biological functions of $\alpha$-syn are not known, the effect of "abnormal" oligomer/aggregate formation and disease-related mutations on $\alpha$-syn function is difficult to determine. The ability of $\alpha$-syn to undergo self-assembly into a multitude of multimeric forms adds further complexity in understanding $\alpha$-syn function and toxicity.

As discussed above, recent work suggests that the native conformation of $\alpha$-syn in cells is in an aggregation-resistant helical tetramer $[15,20,21]$ (Fig. 1B). When these tetramers dissociate, $\alpha$-syn goes to its intrinsically disordered monomeric state where numerous dynamic ensembles likely exist [21]. Alphasynuclein monomers exhibit a relatively high rate of intramolecular diffusion [52]; however, certain experimental conditions induce monomeric conformations (some are also enhanced by disease-related mutations [53]) with significantly slower intramolecular diffusion rates that may facilitate aggregation [52]. Indeed, partially folded $\alpha$-syn is thought to be a precursor in the process of $\alpha$-syn fibril formation, although once again, $\alpha$-syn appears to take on a wide range of folded and/or soluble oligomeric forms depending on its envi- 
ronment (i.e. experimental conditions) (reviewed in [9]). It is noteworthy that monomeric $\alpha$-syn more readily forms aggregates/fibrils in vitro when compared to its propensity to form tetramers in vitro, which suggests the fibrillogenic and tetrameric forms of $\alpha$-syn are generated through different pathways [20,21].

Intermediate stage prefibrillar oligomers and protofibrillar forms can induce damage in neurons both in vitro [54] and in vivo [55] presumably by forming pores in membranes [54-57]. However, intermediate oligomers are relatively unstable and the protofibrils are rapidly sequestered into the larger insoluble fibrils (i.e. Lewy bodies and Lewy neurites) [58]. Interestingly, in vitro studies show that the membrane permeabilizing capacity of protofibrils composed of A53T or A30P $\alpha$-syn is higher than that of the wildtype $\alpha$-syn protofibrils [57]. Moreover, the rate of protofibril formation is higher with these mutant forms $[59,60]$ and the A30P mutation stabilizes this intermediate oligomer [59], suggesting that these disease mutants indeed promote the formation of potentially toxic species of $\alpha$-syn. Finally, the presence of Lewy bodies and Lewy neurites in surviving neurons in PD brains, suggests that these late-stage or mature inclusions are not inherently toxic [61, 62], and may represent a cytoprotective effort of neurons. In fact, the morphology of neurons containing LBs appears more normal compared to those neurons that do not contain these inclusions [61, 62], but it is difficult to determine how the morphological characteristics directly relate to neuron functionality in these post-mortem studies.

After certain energy barriers are overcome, the pathway of $\alpha$-syn aggregation is likely a "self-propagating" event. This is supported by the polymerization kinetics observed in numerous in vitro studies $[9,59,63$, 64] and evidence that $\alpha$-syn oligomers serve as seeds for further polymerization in a dose-dependent fashion [65-67]. This is particularly important in the context of disease pathogenesis considering recent work that suggests aggregated $\alpha$-syn can spread from cell to cell and induce misfolding and oligomerization of $\alpha$-syn in the recipient cell. Thus, yet-to-be defined toxic forms of $\alpha$-syn may exhibit prion-like spread throughout the nervous system [68-71]. This contention supports the Braak staging hypothesis of PD, which postulates a peripheral origin of the disease that spreads to the CNS over time in a process mediated via the cell-to-cell transfer of $\alpha$-syn [72]. Moreover, the demonstration that ectopically applied $\alpha$-syn can cause putatively toxic changes in the endogenous protein (i.e. aggregation of $\alpha$-syn in recipient cell) [65] strengthens the hypothesis that modulation of $\alpha$-syn indeed is directly causative in neuronal toxicity.

\section{Targeting $\alpha$-Syn as a therapeutic modality}

Initial preclinical therapeutic approaches aimed at reducing $\alpha$-syn expression either at the mRNA or protein level were based on the strong links between $\alpha$-syn and PD (familial and sporadic forms), and the common conception that $\alpha$-syn pathology represents a toxic gain-of-function [73]. The expression of the $\alpha$ syn mRNA was successfully reduced through the use of RNAi (either as shRNA, miRNA, or direct delivery of siRNA) in rodents and primates [74-76]. However, it is noteworthy that a significant reduction of $\alpha$-syn in the adult rodent can produce severe nigral neuron loss [75] (further discussed below) (Fig. 2). Alternatively, an immunization-based approach is currently being pursued as a therapeutic intervention aimed at reducing $\alpha$-syn load. The $\alpha$-syn vaccine (PD01A) is currently in a phase I clinical trial (June 2012) (http://www.affiris. $\mathrm{com} / \mathrm{html} / \mathrm{en} / \mathrm{presse}$ medien/pressemeldungen.html) in order to evaluate the safety and tolerability of its use. This method can reduce $\alpha$-syn aggregation, particularly in the presynaptic boutons of immunized transgenic mice expressing human $\alpha$-syn [77]. However, severe caution is recommended when pursuing strategies that might reduce and/or remove $\alpha$-syn expression considering that the role of $\alpha$-syn in neurons is yet to be elucidated and the protein provides a crucial function to neurons. Indeed, an improved understanding of the consequences from targeting $\alpha$-syn is required and without it additional approaches should not be taken to the clinic. Perhaps a more viable approach is to breakup aggregates and/or inhibit their formation altogether (i.e. via small molecule-based approaches) [78]; however, one must be cautious not to facilitate the formation of toxic oligomeric species when taking these approaches.

\section{Role of $\alpha$-syn in disease models}

Due to the prevalence of $\alpha$-syn in both sporadic and heritable forms of PD, genetic manipulation of this protein in rodents and in primates has become a popular tool to model PD and other synucleinopathies. A vast array of transgenic (knock-in) rodents exist that express wildtype or disease-related mutant forms of $\alpha$-syn under control of different promoters such as the $\mathrm{TH}$, thy- 1 , or prion promoter, among others (reviewed in detail in [79, 80]). Although some of these models exhibit a distinct DAergic phenotype and 

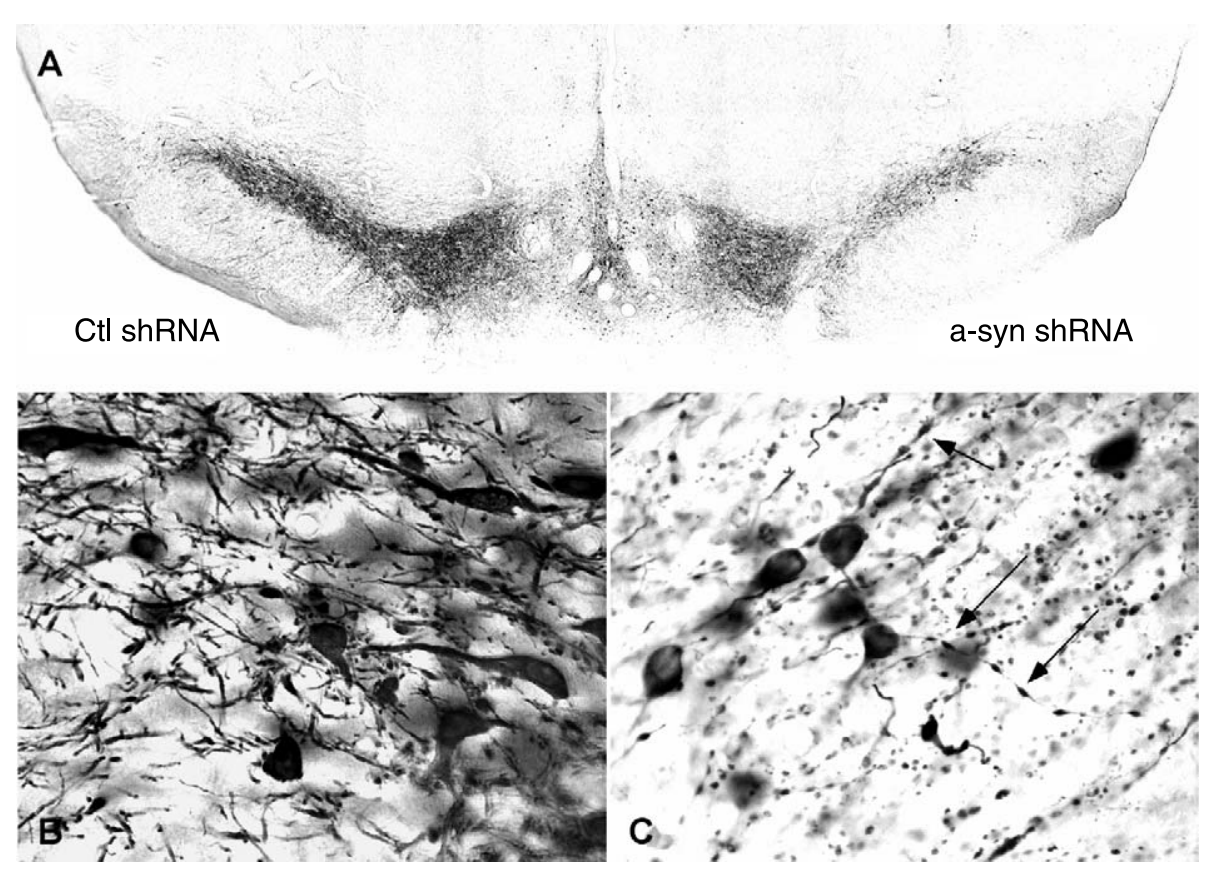

Fig. 2. shRNA-mediated silencing in the adult rat results in loss of TH+SN neurons. A-C. TH immunoreactivity. A. rAAV-mediated overexpression of a shRNA $\left(2.6 \times 10^{12}\right.$ particles/ml) [75] (right hemisphere) designed against $\alpha$-syn (resulting in approximately $85 \%$ loss of $\alpha$-syn protein) results in severe loss of TH+ cells of the SN 28 days following viral delivery. No neuronal loss is observed in the control-shRNA injected hemisphere (left hemisphere). B. Neurons in control injected hemisphere appear normal; however, neurons in the $\alpha$-syn shRNA treated hemisphere exhibit dystrophic and fragmented neurites $(\mathbf{C})$, similar in morphology to dystrophic neurites observed with human $\alpha$-syn overexpression in rodents [94] and non-human primates [179].

some forms of $\alpha$-syn aggregation, germline expression of $\alpha$-syn has largely failed to recapitulate the neuronal loss observed in PD. To date, only two germline transgenic models have demonstrated nigral DAergic neurodegeneration with age. Expression of a double mutant form (A30P and A53T) from the rat $\mathrm{TH}$ promoter results in loss of nigral $\mathrm{TH}+$ neurons starting at 2 months of age [81]. A model that produces twenty to thirty-fold overexpression (as compared to endogenous levels) of a truncated version of human $\alpha$-syn (amino acids 1-130) also produces severe nigral neurodegeneration [82]. Interestingly, animals homozygous for the insertion of truncated human $\alpha$-syn did not survive past the embryonic state suggesting $\alpha$-syn related toxicity early in embryogenesis [82]. In contrast, conditional knock-in $\alpha$-syn (A53T) mutant mice display significant SNc degeneration following induction (two-fold overexpression) in mature animals, with the accompanying motor phenotype [83]. These conditional animals exhibit a decrease in the important DAergic transcription factor Nurr1. Interestingly, Nurr1 is similarly reduced in nigral neurons containing $\alpha$-syn inclusions in human PD [84], and mutations that reduce Nurr1 expression can cause PD [85]. One Nurr1 target is the receptor tyrosine kinase RET [86], an important receptor for glial cell-line derived neurotrophic factor (GDNF)mediated pro-survival signaling. This suggests that modulation of $\alpha$-syn expression may indirectly result in the impaired trophic support of DA neurons. Similar to the conditional knock-in animals, virally-mediated overexpression of wildtype or mutant human $\alpha$-syn in adult animals leads to a significant and progressive degeneration of $\mathrm{SNc}$ neurons both in rodents and in non-human primates. Moreover, with virallymediated overexpression nigral loss is observed at transgene expression levels of only 2 times that of normal [87]. One interesting observation associated with virally-mediated $\alpha$-syn lesion is that it is refractory to treatment with GDNF [88], a neuroprotective approach that is well established in toxin-induced models such as the 6-hydroxydopamine (6-OHDA) and 1-methyl4-phenyl-1,2,3,6-tetrahydropyridine (MPTP) models [89-92]. This discrepancy between treatment outcomes highlights the fundamental differences in downstream cellular consequences between different model systems. On one hand, the toxin-induced models are acute and result from the formation of toxic reactive oxygen species and the inhibition of mitochondrial respiration. On the other hand, the viral vector-mediated 
$\alpha$-syn lesion is a chronic and progressive model that exhibits protracted cellular dysfunction, aggregate formation, and impaired axonal transport [93-95]. Thus, these models may represent distinct molecular pathologies represented in PD and potential therapeutic interventions should be tested in numerous model systems as a better predictor of treatment outcome in human disease [88].

Transgenic invertebrate $\alpha$-syn models such as the fruit fly (Drosophila melanogaster) or the worm (Caenorhabditiselegans) more consistently recapitulate key aspects of PD. For example, transgenic flies exhibit a progressive loss of DA neurons with age, the formation of LB-like inclusions, and DOPA-responsive motor symptoms [96]. Similarly, overexpression in $C$. elegans is accompanied by the formation of LB-like aggregates, DAergic neurodegeneration, as well as a motor phenotype [97]. Interestingly, these invertebrates apparently lack a homologue of $\alpha$-syn, and while it is tempting to suggest these data support direct $\alpha$-syn toxicity the fact that a completely foreign protein is introduced into the organism makes the results of these studies difficult to interpret.

\section{$\alpha-S Y N$ BIOLOGICAL FUNCTIONS}

Currently, the biological functions of $\alpha$-syn are not known; however, there is a significant amount of ongoing work aimed at filling this gap in our knowledge. The functional repertoire of $\alpha$-syn is studied largely by the way of determining the abnormalities following overexpression, loss of expression, or expression of mutant forms of $\alpha$-syn. The majority of studies suggest $\alpha$-syn plays a role in synaptic vesicle regulation, mitochondrial function, and/or DA handling and synthesis, but the list of other potential functions is long and continues to grow. We will highlight some of the important findings in each of these categories (Table 1).

\section{$\alpha$-syn-mediated regulation of synaptic vesicles}

The initial observations that $\alpha$-syn is predominately a presynaptic protein that extensively co-localized with synaptic vesicles markers hinted at an important role for $\alpha$-syn in synaptic function. In fact, $\alpha$-syn is known to interact with numerous synaptic proteins including synaptophysin, synapsin I, SNAP-25, synaptobrevin 2/vesicle-associated membrane protein 2 (VAMP2)

Table 1

Biological functions of $\alpha$-syn protein

\begin{tabular}{|c|c|c|c|}
\hline Proposed function & Mechanisms & Related interacting partners & References \\
\hline $\begin{array}{l}\text { Synaptic vesicle } \\
\text { regulation }\end{array}$ & $\begin{array}{l}\text { Maintain vesicle reserves } \\
\text { Reduce vesicle mobility } \\
\text { Reduce vesicle docking via SNARE complex* } \\
\text { Reduce neurotransmitter release* }\end{array}$ & $\begin{array}{l}\text { Synaptophysin, synapsin I, } \\
\text { SNAP-25, synaptobrevin } \\
\text { 2/VAMP2, VMAT2, CSP } \alpha\end{array}$ & $\begin{array}{l}{[98,101-110]} \\
{[99,100,111]^{*}}\end{array}$ \\
\hline $\begin{array}{l}\text { Mitochondrial } \\
\text { function }\end{array}$ & $\begin{array}{l}\text { Inhibit fusion } \\
\text { Promote fission } \\
\text { Mitochondrial morphology }\end{array}$ & Unknown & {$[11,112-118]$} \\
\hline $\mathrm{Ca}^{2+}$ Homeostasis & $\begin{array}{l}\text { Mitochondrial-ER Ca trafficking } \\
\text { Mitochondrial anion channel regulation } \\
\text { Cytosolic } \mathrm{Ca}^{2+} \text { regulation }\end{array}$ & Calmodulin, mortalin/Grp75 & [118-126] \\
\hline DA handling & $\begin{array}{l}\text { Increase DA reuptake* } \\
\text { Increase DAT function* } \\
\text { DAT membrane localization } \\
\text { Tethering DAT to microtubules } \\
\text { Increase VMAT on vesicles }\end{array}$ & $\begin{array}{l}\text { DAT } \\
\text { Tubulin } \\
\text { VMAT }\end{array}$ & $\begin{array}{c}{[110,128,130,131]} \\
{[129,132,133]^{*} ;[134]^{*}}\end{array}$ \\
\hline DA biosynthesis & $\begin{array}{l}\text { Reduce TH activity } \\
\text { Reduce AADC activity }\end{array}$ & $\begin{array}{l}\text { TH, PP2A } \\
\text { AADC }\end{array}$ & {$[137-140]$} \\
\hline Chaperone & $\begin{array}{l}\text { Unknown } \\
\text { Prevent aggregation }\end{array}$ & $\begin{array}{l}\text { 14-3-3 proteins } \\
\text { DJ-1 }\end{array}$ & [143-148] \\
\hline Cytoskeletal function & Unknown (Vesicle transport) & $\begin{array}{l}\text { Tubulin, tau, MAP1b, actin and } \\
\text { Rab small GTPases }\end{array}$ & {$[141,142]$} \\
\hline $\begin{array}{l}\text { Protein } \\
\text { phosphorylation }\end{array}$ & Unknown (numerous possibilities) & $\begin{array}{l}\text { ERK 1/2, PKC, CK1, MARK, } \\
\text { CaM Kinase II, PP1 }\end{array}$ & {$[141-143]$} \\
\hline $\begin{array}{l}\text { Gene expression } \\
\text { (Nucleus) }\end{array}$ & $\begin{array}{l}\text { Histone deacetylation } \\
\text { Transcription regulation }\end{array}$ & $\begin{array}{l}\text { Histones } \\
\text { Promoters (e.g. PGC1-alpha, \& others) }\end{array}$ & {$[149-151]$} \\
\hline Lipid membranes & Unknown (Lipid metabolism) & Lipid rafts, Phospholipase D2 & {$[153-156]$} \\
\hline
\end{tabular}


$[98,99]$. However, not all studies support an interaction between $\alpha$-syn and SNARE-related proteins due to a lack of co-immunoprecipitation [100], but this might be indicative of a weak and/or transient interaction.

Numerous studies have identified a link between $\alpha$ syn and regulation of the synaptic vesicle reserves, vesicle trafficking, and neurotransmitter release. Some studies demonstrate that $\alpha$-syn may play a role in maintaining the appropriate amount of synaptic vesicles in the reserve pool in neurons. For instance, $\alpha$-syn knockout mice have less vesicles in the reserve pool [101], and hippocampal neurons exhibit signatures indicative of faster depletion of the reserve synaptic vesicle pool and slower replenishment of the pool following repetitive prolonged stimulations [101]. Overexpression of $\alpha$-syn in cultured hippocampal neurons causes a reduction in vesicle mobility and the size of the reserve vesicle pool, while the opposite was found in cultured neurons derived from $\alpha$-syn null mice [102]. Further supporting the role of $\alpha$-syn in vesicle trafficking, studies have shown that $\alpha$-syn inhibits endoplasmic reticulum-Golgi complex vesicle trafficking in yeast [103-105] and non-neuronal cell lines [106]. In PC12 cells and chromaffin cells, overexpression of wild-type and mutant $\alpha$-syn causes decreased catecholamine release and an accumulation of "docked" synaptic vesicles without affecting the size of the vesicle pool [107] which is also true with virally-mediated overexpression of $\alpha$-syn in vivo [108, 109]. Interestingly, in two $\alpha$-syn null mouse lines basal and evoked DA release was enhanced [110], which is consistent with the notion that $\alpha$-syn is a negative regulator of neurotransmitter release. Together, these studies suggest $\alpha$-syn acts as a negative regulator of synaptic vesicle release, possibly by reducing vesicle mobility and pool size. However, some evidence suggests $\alpha$-syn can enhance neurotransmitter release [111] and promote SNARE complex formation, an effect that is dependent on the C-terminal domain [99]. Moreover, SNARE complex formation is impaired when all three isoforms of $\alpha$-syn are knocked out in mice [99].

Despite the somewhat discordant findings in the literature, all of these studies clearly indicate that $\alpha$-syn is important in modulating synaptic function through modulating the synaptic vesicle pool, trafficking and/or vesicle exocytosis. One hypothesis that may help reconcile some of these discrepancies is that $\alpha$-syn serves multiple, context-dependent functions related to synaptic vesicles. For instance, $\alpha$-syn may maintain reserve pool size by modulating mobility through cytoskeletal interactions, and once a vesicle is translocated to the synaptic active zone $\alpha$-syn acts in concert with other SNAP/SNARE-complex proteins to determine whether vesicles fuse and release neurotransmitters. By extension, overexpression, mutant forms, and complete loss of $\alpha$-syn will likely have a dynamic detrimental effect on synaptic function and neurotransmission (an effect that will vary with experimental conditions and detection will depend upon outcome measures).

\section{$\alpha$-Syn and mitochondrial function}

A compelling biological function attributed to $\alpha$-syn that is coming to light is its apparent ability to influence mitochondrial function. Multiple independent reports demonstrate that $\alpha$-syn localizes to mitochondria in cultured cells under various experimental conditions [11, 112-114] and in nigral DA neurons of mice [115] and humans [114]. In cultured human DAergic neurons, $\alpha$-syn is imported into mitochondria in an energy and transmembrane potential-dependent fashion, localizes primarily with the inner membrane, and mitochondrial localization is dependent on a cryptic mitochondrial targeting sequence within the amino terminus (i.e. aa 1-32) of $\alpha$-syn [114]. Alpha-synuclein appears to inhibit mitochondrial fusion as reducing its expression in neuronal cell lines results in increased fusion and more tubular mitochondria [116], while overexpressing $\alpha$-syn in neuronal and non-neuronal cell lines induces fission leading to increased mitochondrial fragmentation [116-118]. Although investigated under conditions that produce $\alpha$-syn toxicity (i.e. overexpression), the evidence that $\alpha$-syn affects mitochondrial morphology and dynamics may be indicative of a normal biological role for $\alpha$-syn in this capacity. These findings are interesting in light of $\alpha$-syn's ability to modulate vesicle dynamics at the synapse and reduce ER-Golgi complex vesicle trafficking (as described above), which involves membrane fusion. Perhaps one of $\alpha$-syn's biological functions is to regulate membrane fission and fusion events, whether it is docking of synaptic vesicles at the active zone or fission/fusion of mitochondria. Further experimentation is required to specifically address and confirm this hypothesis.

Calcium homeostasis and mitochondrial functionality have long been implicated in the pathogenic processes of PD and other neurodegenerative diseases $[118,119]$. Subsequently, the findings that indicate $\alpha$-syn may influence mitochondrial function through modifying calcium handling/homeostasis are particularly intriguing in the context of normal $\alpha$-syn biology and disease pathogenesis. An interesting set of experi- 
ments by Cali and coworkers demonstrated that $\alpha$-syn controls mitochondrial $\mathrm{Ca}^{2+}$ homeostasis by modulating the interaction between mitochondria and the ER [118]. In SH-SY5Y and HeLa cell lines, the expression of $\alpha$-syn caused enhanced $\mathrm{Ca}^{2+}$ transients without affecting basal $\mathrm{Ca}^{2+}$ levels or mitochondrial $\mathrm{Ca}^{2+}$ uptake machinery, and this effect was dependent on the C-terminus of $\alpha$-syn. These $\alpha$-syn-mediated effects were due to an increase in ER-mitochondrial interactions, which was confirmed by knocking down $\alpha$-syn expression via siRNA (i.e. caused reduced $\mathrm{Ca}^{2+}$ uptake). One important implication of this set of experiments is that they indicate an intricate balance of $\alpha$-syn levels that is critically important to maintaining mitochondrial functionality and mitochondrial $\mathrm{Ca}^{2+}$ homeostasis. Alpha-synuclein also interacts with mortalin (a.k.a. Grp75) [120, 121], which is a chaperone protein involved in coupling inositol triphosphate 3 receptors to voltage-dependent anion channels on the outer mitochondrial membrane to regulate $\mathrm{Ca}^{2+}$ homeostasis [122]. Perhaps $\alpha$-syn acts in concert with mortalin as a bridging chaperone to regulate mitochondrial $\mathrm{Ca}^{2+}$ levels by way of the endoplasmic reticulum.

In addition, $\alpha$-syn may play a more general role in cellular $\mathrm{Ca}^{2+}$ homeostasis as it binds calmodulin in a $\mathrm{Ca}^{2+}$-dependent fashion [123]. Moreover, longlasting $\mathrm{Ca}^{2+}$ transients following both spontaneous and stimulus-induced $\mathrm{Ca}^{2+}$ activity are augmented in the cortex of transgenic mice expressing human $\alpha$-syn [124]. These in vivo findings have been confirmed with in vitro studies using neuronal cell lines (i.e. SH-SY5Y cells), which indicate that $\alpha$-syn overexpression causes an increase in stimulation-induced $\mathrm{Ca}^{2+}$ entry into cells $[125,126]$. Again, these effects were explored in the context of being toxic to cells but they may be indicative of normal biological function of $\alpha$-syn. Collectively, these studies implicate $\alpha$-syn as an important component of the mitochondrial function/ $/ \mathrm{Ca}^{2+}$ homeostasis axis that is critical to neuron function and survival.

\section{$\alpha$-Syn in DA handling and biosynthesis}

A substantial number of reports indicate that $\alpha$ syn can regulate DA synaptic tone via modulating the dopamine transporter (DAT) and DA synthesis [127]. In fact, $\alpha$-syn can regulate both the norepinephrine and serotonin transporters as well [127]. The direct interaction with DAT is mediated by the carboxy terminus of DAT [128] and the NAC region of $\alpha$-syn [128, 129]. Currently, the exact nature of the relationship between $\alpha$-syn and DAT function is somewhat controversial.
The controversy centers around studies that indicate $\alpha$-syn facilitates DAT expression and function versus those that indicate $\alpha$-syn has the opposite effect. Both in vitro [130, 131] and in vivo [110] studies using loss-of $\alpha$-syn models suggest that $\alpha$-syn increases DAT expression and functionality. Knock down of $\alpha$ syn in neuronal cell lines or knockout mice exhibit reduced DAT expression, less plasma membrane localized DAT, and impaired DA reuptake. Interestingly, eliminating or reducing $\alpha$-syn increases basal and evoked levels of DA release, and increases the amount of VMAT2 on synaptic vesicles [130]. Some studies show $\alpha$-syn can potentiate DA uptake via DAT modulation in neurons and non-neuronal cells [128]. The other side of the debate is supported by studies that show the overexpression of $\alpha$-syn reduces DAT expression and DAT activity (i.e. DA uptake $\mathrm{V}_{\max }$ ) using a number of experimental paradigms [129, 132, 133]. Interestingly, inhibition of DAT function precedes retrograde neurodegeneration following viral-mediated delivery of $\alpha$-syn to the nigrostriatal tract [109]. Alpha-synuclein likely modulates DAT functionality, at least in part, by affecting the distribution of DAT to the plasma membrane via a process that involves tethering DAT (likely on presynaptic vesicles) to microtubules [133]. At first glance, these data may seem to oppose one another; however, what if $\alpha$-syn serves two functions in regulating DAT? Both sets of data could be explained if $\alpha$-syn were critically important in targeting vesicles containing DAT to the appropriate subcellular localization for storage (via MT tethering) and the proper delivery of DAT to the plasma membrane to maintain membraneassociated DAT levels. Indeed, in this hypothetical paradigm both a loss of $\alpha$-syn and excess $\alpha$-syn would similarly lead to DAT mislocalization, reduced levels of DAT at the membrane and reduced DA reuptake.

Of note, previous studies using $\alpha$-syn null mice did not observe any effects on DAT [134]. While the underlying reasons of the discrepant findings in the literature are unclear, they may be due to differences in experimental paradigms and the choice of transgenic models used. Nonetheless, it appears that $\alpha$-syn can indirectly regulate DA uptake, recycling and bioavailability via modulating DAT distribution and functionality in neurons $[135,136]$.

Independent of DAT-related mechanisms, studies indicate that $\alpha$-syn can modulate DA biosynthesis. In fact, $\alpha$-syn directly interacts with TH (as indicated by co-immunoprecipitation) and acts as a negative regulator of TH activity [137]. The inhibition of TH by $\alpha$-syn is mediated by a mechanism involving the dephosphorylation of TH at Ser40 by PP2A, and it appears that 
$\alpha$-syn interacts directly with PP2A as well $[138,139]$. Moreover, $\alpha$-syn interacts with aromatic amino acid decarboxylase, the enzyme that converts L-dopa to DA, and causes decreased AADC activity further supporting a role of $\alpha$-syn in DA biosynthesis [140]. The role of $\alpha$-syn in DA biosynthesis and DA handling may be intimately linked to disease-related malfunctions or loss-of-function in $\alpha$-syn that leads to the selective dysfunction and degeneration of DA neurons in PD.

\section{$\alpha$-Syn and other potential biological functions}

Certainly, the biological functions discussed above are supported by numerous studies, but there are additional potential functions of $\alpha$-syn. Some insight can be gleaned from the growing list of $\alpha$-syn interacting partner proteins [141, 142]. The suggestion that $\alpha$-syn could act as a chaperone is based on sequence homology with 14-3-3 proteins and a direct interaction between $\alpha$-syn and 14-3-3 proteins [143]. In addition to acting as a chaperone, $\alpha$-syn may be regulated by chaperones. For instance, DJ-1 (a.k.a. PARK7), a gene that is mutated in autosomal recessive early-onset PD, acts as a chaperone for $\alpha$-syn [144]. Indeed, DJ-1 appears to inhibit the aggregation and subsequent cell toxicity associated with overexpressing human $\alpha$-syn and PD-related mutant forms of $\alpha$-syn (e.g. A53T) in in vitro assays [145] and numerous cell-types in culture [146-148]. Interestingly, the protective chaperone activity of DJ-1 with $\alpha$-syn is dependent on the redox state of DJ-1 [145, 146] and a mutant form of DJ-1 associated with inherited PD (i.e. L166P DJ-1) does not provide the protective effects of wild-type DJ-1 [146, 147]. Lastly, the protective effects of DJ-1 may involve the upregulation of Hsp70 as well [147, 148]. Whether DJ-1 is important in stabilizing non-toxic forms of $\alpha$ syn under normal conditions remains unknown and future studies are required to determine whether chaperones are involved in "normal" $\alpha$-syn function.

In the initial discovery of $\alpha$-syn, the protein was found in the nucleus of neurons [3]. It appears that nuclear $\alpha$-syn may play a role in gene expression directly through transcription factor regulation and/or indirectly through epigenetics mechanisms. Alphasynuclein may impact transcriptional regulation via binding numerous promoters [149]. Interestingly, $\alpha-$ syn binds the PGC1 alpha promoter both in vitro and in vivo (including in neurons of aged and PD patients), which may have effects on mitochondrial function because PGC1 alpha is an important mitochondrial transcription activator [149]. Additionally, $\alpha$-syn can bind to histones suggesting a potential functional relationship between them [150,151], but histones can increase $\alpha$-syn aggregation and the co-localization of $\alpha$-syn with histones is increased in a PD model (i.e. paraquat exposure) [150]. The "normal" presence of $\alpha$-syn in the nucleus suggests a biological function in this cellular compartment; however, $\alpha$-syn (including mutant forms of $\alpha$-syn) may mediate neurotoxicity via the nucleus by inhibiting histone acetylation [151]. Nonetheless, the precise function(s) of nuclear $\alpha$-syn are still being identified, and the potential role of nuclear $\alpha$-syn in normal cell function and synucleinopathies such as PD remains unresolved.

Direct interactions between $\alpha$-syn and important cytoskeleton proteins, such as tubulin, tau, MAP1b, actin and Rab small GTPases, among others have been identified. It is tempting to speculate that the cytoskeletal interactions of $\alpha$-syn might be intimately linked to its function in modulating synaptic vesicle distribution between the reserve pool and synaptic active zone (as discussed above), and potentially mitochondrial localization.

Alpha-syn also interacts directly with multiple kinases, such as extracellular signal-regulated kinase (ERK)1/2 and protein kinase C (PKC) [143], which are involved in a large set of biological functions. For example, PKC is linked to regulating axonal transport [152] and oxidative stress [100], among other processes, and while the exact nature of these interactions awaits further elucidation they could be indicative of an important role of $\alpha$-syn in cytoskeleton functionality.

In addition to the membrane interactions outlined above, $\alpha$-syn appears to interact with lipid rafts [153] and phospholipase D2 [154-156] in the plasma membrane, and thus, might play a role in regulating plasma membrane dynamics. Taken together, the majority of studies points towards $\alpha$-syn as an indispensable protein likely involved in numerous cellular functions that are critical to neuron function and survival.

\section{LOSS OF FUNCTION HYPOTHESIS}

\section{$\alpha$-Syn knockout}

Several germline $\alpha$-syn knockout mice have been created [101, 134, 157-159], but a majority of these animals do not display neurodegeneration. However, one report evaluating the $\alpha$-syn null mouse found that germline removal of the $\alpha$-syn gene results in a significant but low level of neurodegeneration in the SNc early during development [158]. The observed difference in these mouse lines may be explained by the fact that phenotypes due to the targeted genetic deletions 
of specific genes within the DA neurons varies significantly depending on the genetic backgrounds of the mice [160]. Regardless, subtle phenotypes including impaired DA release and reduced striatal DA content have been reported in all adult and aged $\alpha$-syn null mice $[157,161]$. Moreover, these mice display reduced sensitivity to the neurotoxin MPTP [134, 162]. In contrast, virally-mediated delivery of shRNAs targeting $\alpha$-syn in the adult rodent midbrain results in severe, dose-dependent, neurodegeneration of nigral neurons [74, 75] (Fig. 2). Further confirming the specificity of these effects, Gorbatyuk and colleagues demonstrated that shRNAs targeting different sites in the $\alpha$-syn mRNA reproduced the nigral neuron degeneration [75]. Importantly, supplementation with endogenous rat $\alpha$-syn rescued the neurons from degeneration, demonstrating that neuronal toxicity was explicitly due to loss of $\alpha$-syn in mature neurons [75]. Similarly, neurotoxicity was seen when rat nigral neurons were simultaneously transduced with viruses to overexpress human $\alpha$-syn and knockdown human $\alpha$-syn mRNA (via shRNA). However, it was unclear from this study whether the shRNA had an effect on endogenous levels of rat $\alpha$-syn [74]. Conversely, direct infusion of a siRNA into the non-human primate $\mathrm{SN}$ resulting in approximately $40 \%$ reduction of $\alpha$-syn protein failed to produce neurodegeneration [76]. These findings agree with those reported by Gorbatyuk and coworkers, who demonstrated that toxicity due to loss of $\alpha$-syn is dependent on the remaining levels of $\alpha$-syn protein.

Unfortunately, it is difficult to determine whether germline-based approaches are appropriate for understanding sporadic, adult-onset disease-related processes. Indeed, one likely source of discrepancies between germline manipulated transgenic mice (both knock-in and knockout mice), and post-developmental $\alpha$-syn manipulations (shRNA-mediated silencing, virally mediated overexpression, or conditional knockin) is the potential compensatory changes in other genes that occur when $\alpha$-syn is manipulated in the germline. Some of these potential compensatory changes may include genes that directly compensate for crucial roles of $\alpha$-syn as well as the enhancement of pro-survival pathways that prime susceptible DAergic cells providing a finite level of protection against insults such as oxidative stress [161]. Indeed, genome array comparisons between $\alpha$-syn knockout and wildtype mice revealed that 369 genes were differentially expressed [163]. Among these gene changes, both ERK2 and apoptosis-related genes were affected indicating that pathways modulating neuronal survival are differentially regulated in the $\alpha$-syn ${ }^{-/-}$ mouse. Direct comparisons of genome array data from the $\alpha$-syn ${ }^{-/-}$mouse and acute RNAi knockdown in vitro indicate that only 3 gene changes overlap between the two knockdown approaches when compared to control [164]. Thus, the knockout animals may have an unnaturally high tolerance for future insults, but this compensation does not appear to arise from increased expression of other synuclein family members. For example, the levels of $\beta$-syn protein in $\alpha$-syn null mice are similar to that of wildtype mice $[157,159]$. However, the third member of the synuclein family is upregulated in double synuclein knockout animals $\left(\alpha^{-/-} / \beta^{-/-}\right.$and $\left.\alpha^{-/-} / \gamma^{-/-}\right)[158$, 165]. Moreover, animals void of all three forms of synuclein $(\alpha, \beta, \gamma)$ do not display significant neuropathological changes [166, 167] supporting the compensatory effects from currently unidentified elements (e.g. pro-survival genes and/or genes that replace $\alpha$-syn functions) [161]. Collectively, these findings highlight the important point that genetic manipulation in mature neurons is likely to produce a vastly different result from that of germline manipulation.

\section{Loss-of-function hypothesis}

Post-developmental loss of $\alpha$-syn results in rapid neurodegeneration in the nigrostriatal system and DA depletion-related behavioral deficits clearly indicating that $\alpha$-syn plays an important role in maintaining DAergic neuron function and/or survival in adulthood. Depletion in the functional pool of $\alpha$-syn beyond a threshold induces neuron death [75]. Although the report by Gorbatyuk and colleagues is the only work that directly attributes neurodegeneration to loss of $\alpha$-syn, work by others show that a reduction in $\alpha$-syn results in the disruption of cellular processes such as mitochondrial function and autophagy [118]. This conclusion allows for an alternative explanation to the traditional toxic gain-of-function attributed to $\alpha$-syn aggregation in PD. Specifically, one hypothesis of equal explanatory power posits that the incorporation of $\alpha$-syn into aggregates, whether it be oligomers, fibrils, and/or mature Lewy bodies, effectively reduces the amount of functional $\alpha$-syn available. Consequently, $\alpha$-syn related pathology and aggregation represents a de facto loss-of-function mechanism of toxicity [168, 169] (Fig. 1A). This is further compounded by the fact that $\alpha$-syn inclusions appear in the somata of neurons indicating that the aggregates also remove $\alpha$-syn from its normal subcellular compartment (i.e. the synapse). The redistribution and accumulation of $\alpha$-syn during the normal aging process [33] likely increases the 
probability of $\alpha$-syn aggregation and is thus not met with developmental compensation. Indeed, aging, which remains the primary risk factor for developing PD [37], is characterized by reduced cellular stress defenses and compensatory capacity following injury. Moreover, the rate of aggregation may be accelerated by other factors including $\alpha$-syn mutations, elevated expression, and/or post-translational modifications resulting in a more severe and rapid loss-of-function. Additionally, these other factors may directly affect the functionality of $\alpha$-syn in a manner independent of aggregation, but reducing $\alpha$-syn function nonetheless. The role of aging in PD and the results from most studies can be explained through the view that a loss of $\alpha$-syn function is intimately linked to neurodegeneration in PD. Finally, one can easily appreciate that a loss in functionality would lead to neuron dysfunction and death considering the list of potential biological functions attributed to $\alpha$-syn, but truly confirming these hypotheses awaits a more accurate and detailed understanding of exactly what $\alpha$-syn does in neurons. Importantly, the $\alpha$-syn loss-of-function hypothesis does not invalidate the vast body of work that $\alpha$-syn research encompasses. Rather, the majority of studies describing toxicity due to $\alpha$-syn have inferred that the protein itself is directly toxic. Thus, loss-of $\alpha$-syn function could serve as an alternate conclusion in most, if not all, of these instances. Although several reports directly ascribe neurotoxicity to soluble $\alpha$-syn oligomers [54, 55], whether the rate of formation and sequestration of these toxic intermediate-stage protofibrils in experimental conditions truly represents what occurs in human disease remains unknown. The proposition that a mutant protein that has previously been labeled as directly toxic in neurodegenerative disease may actually confer loss of function toxicity is not unique to $\alpha$-syn and its role in PD. Polyglutamine expansions in the protein huntingtin causes Huntingon's disease (HD). Initially, it was argued that huntingtin aggregates were directly toxic, but now it is clear that loss of wildtype huntingtin function is a detrimental factor to neurons (reviewed in [170]), and may be a causative pathological event in HD.

\section{Can $\alpha$-syn be a neuroprotectant?}

More support for the notion that loss of $\alpha$-syn function is detrimental to neurons comes from evidence that $\alpha$-syn provides neuroprotection against various insults both in vitro [171-173] and in vivo. Mice deficient in synaptic cysteine-string protein $\alpha(\operatorname{CSP} \alpha)$, a synaptic protein that is important in SNARE complex assembly, exhibit neurodegeneration and the deletion produces lethality within months of life [174]. When human wildtype $\alpha$-syn overexpression is superimposed on this model, neurodegeneration is significantly reduced and survival is prolonged. Conversely, when the $\operatorname{CSP} \alpha^{-/-}$was crossed with a mouse void of $\alpha$ and $\beta$-synuclein, the pathology was exacerbated [100]. Similarly, in vitro studies show that subjecting primary neurons to chronic oxidative stress results in an upregulation of $\alpha$-syn with the concomitant resistance to apoptosis suggesting that $\alpha$-syn can protect against oxidative stress [175]. Jin and colleagues demonstrated that $\alpha$-syn negatively regulates the expression of $\mathrm{PKC} \delta$, an important mediator of oxidative stress-mediated DAergic cell death. Moreover, the $\alpha$-syn-induced down regulation of $\mathrm{PKC} \delta$ protects against MPP+ (a DAergic neurotoxin) toxicity in N27 cells [176], and primary $\mathrm{TH}+$ neurons isolated from a $\mathrm{TH}$-promoter driven $\alpha$-syn knock-in [177] and in $\alpha$-syn overexpressing MN9D cells [173]. Interestingly, PKC $\delta$ was significantly reduced in DAergic neurons in the $\mathrm{CSP} \alpha^{-/-} / \alpha-$ syn $^{-/-} / \beta$-syn ${ }^{-/-}$mice $[100,176]$. Similarly, overexpression of $\alpha$-syn may prevent cell death following oxidative stress through inhibition of c-Jun $\mathrm{N}$-terminal kinase activity, an effect not seen with $\beta$ synuclein overexpression [178]. Although the direct mechanism where by $\alpha$-syn potentiates neuronal survival is yet to be elucidated, a growing body of evidence demonstrates that in certain conditions $\alpha$-syn serves as to promote neuronal survival.

\section{A model for $\alpha$-syn loss-of-function}

A clear picture is emerging from the studies highlighted above - there is an intricate balance between too little and too much $\alpha$-syn in neurons. Too little of the protein sensitizes the cell to further insults, and a dramatic loss of the protein results in rapid cell death. Conversely, both human and animal data inform us that increasing the expression, even minimally, results in a significant increase in the disease phenotype. Moreover, changing the localization of $\alpha$-syn within the cell seems to be intimately tied to toxicity. Based on these premises, we propose the following model of $\alpha$-synbased neurotoxicity: In its native state, $\alpha$-syn exists in a dynamic equilibrium between an intrinsically disordered monomer and a stable soluble tetramer (possibly favoring the monomeric state [22]). The tetramers may represent a state in which the cell "stores" an inert form of the protein, and the dissociation of this complex into a disordered monomer may represent its conversion to a functional state. While $\alpha$-syn tetramers are fairly 
thermodynamically stable, they do not readily form in vitro, and $\alpha$-syn monomers require less energy to form the soluble oligomers and intermediate protofibrils that lead to further self-assembly into insoluble fibrils. Together, these findings suggest there might be secondary factors (e.g. a chaperone) in situ that facilitate the formation of the stable tetramer, but currently these factors are unknown. While the mechanisms that push $\alpha$-syn monomers down one path or the other (i.e. stable non-toxic tetramers versus fibrillogenic oligomers and then fibrils) are still not entirely understood, the concentration of $\alpha$-syn in the neuron appears to be a clear determinant (i.e. more $\alpha$-syn facilitates aggregation). With normal aging, the protein is concentrated to the cell body and when coupled with post-translational modifications (i.e. phosphorylation, nitration, truncation, among others), or enhanced expression due to genetic multiplications or promoter polymorphisms, or with mutations that increase the stability of oligomers and decrease the stability of tetramers, the likelihood of fibril formation increases. Concomitantly, once insoluble fibrils appear, the reaction will be further pushed in the favor of the production of more insoluble inclusions. Ultimately, the sequestration of $\alpha$-syn into these inclusions will bring the concentration of soluble $\alpha$-syn at the synapse below that which is required for proper cellular functions. Eventually, neuron dysfunction leads to neuron death and the clinical and neuropathological manifestations of PD appear.

\section{CONCLUSION}

The protein $\alpha$-syn is highly conserved across species and is expressed throughout the brain starting early in CNS development. Thus, as the role of this protein in specific cellular processes is better understood it is not entirely surprising that $\alpha$-syn is extremely important in normal DAergic neuron function. However using the genetic tools at hand to manipulate this protein in vitro and in vivo has in many cases yielded rather divergent results, further complicating our understanding of this protein. Although it is uncontested that $\alpha$-syn plays a crucial, albeit largely unknown, part in PD pathogenesis it is likely that we will learn that $\alpha$-syn intersects the molecular mechanisms underlying neurodegeneration at multiple points. The formation of toxic oligomers, the loss of functional soluble protein, and the dysregulation of crucial cellular processes may share equal burden in the formation of toxic events that either sensitize the neuron to other insults, or sets in motion a process that in itself culminates in cell death.

\section{ACKNOWLEDGMENTS}

We acknowledge Dr. Caryl S. Sortwell for critical review of the manuscript.

This work was supported by the NIH (NINDS) Morris K. Udall Center of Excellence for Parkinson's Disease at Michigan State University (P50NS058830, NMK).

\section{CONFLICT OF INTEREST}

The authors have none to declare.

\section{REFERENCES}

[1] Goedert M, Clavaguera F, \& Tolnay M (2010) The propagation of prion-like protein inclusions in neurodegenerative diseases. Trends Neurosci, 33, 317-325.

[2] Surguchov A (2008) Molecular and cellular biology of synucleins. Int Rev Cell Mol Biol, 270, 225-317.

[3] Maroteaux L, Campanelli JT, \& Scheller RH (1988) Synuclein: A neuron-specific protein localized to the nucleus and presynaptic nerve terminal. J Neurosci, 8, 2804-2815.

[4] Chen X, de Silva HA, Pettenati MJ, Rao PN, St GeorgeHyslop P, Roses AD, Xia Y, Horsburgh K, Ueda K, \& Saitoh $\mathrm{T}$ (1995) The human NACP/alpha-synuclein gene: Chromosome assignment to 4q21.3-q22 and TaqI RFLP analysis. Genomics, 26, 425-427.

[5] Beyer K, Humbert J, Ferrer A, Lao JI, Carrato C, Lopez D, Ferrer I, \& Ariza A (2006) Low alpha-synuclein 126 mRNA levels in dementia with Lewy bodies and Alzheimer disease. Neuroreport, 17, 1327-1330.

[6] Ueda K, Saitoh T, \& Mori H (1994) Tissue-dependent alternative splicing of mRNA for NACP, the precursor of non-A beta component of Alzheimer's disease amyloid. Biochem Biophys Res Commun, 205, 1366-1372.

[7] George JM (2002) The synucleins. Genome Biol, 3, REVIEWS3002.1-REVIEWS3002.6.

[8] Weinreb PH, Zhen W, Poon AW, Conway KA, \& Lansbury PT Jr. (1996) NACP, a protein implicated in Alzheimer's disease and learning, is natively unfolded. Biochemistry, $\mathbf{3 5}$, 13709-13715.

[9] Uversky VN (2007) Neuropathology, biochemistry, and biophysics of alpha-synuclein aggregation. J Neurochem, 103, 17-37.

[10] Bernado P, Bertoncini CW, Griesinger C, Zweckstetter M, \& Blackledge M (2005) Defining long-range order and local disorder in native alpha-synuclein using residual dipolar couplings. J Am Chem Soc, 127, 17968-17969.

[11] Nakamura K, Nemani VM, Wallender EK, Kaehlcke K, Ott M, \& Edwards RH (2008) Optical reporters for the conformation of alpha-synuclein reveal a specific interaction with mitochondria. J Neurosci, 28, 12305-12317.

[12] Bertoncini CW, Jung YS, Fernandez CO, Hoyer W, Griesinger C, Jovin TM, \& Zweckstetter M (2005) Release of long-range tertiary interactions potentiates aggregation of natively unstructured alpha-synuclein. Proc Natl Acad Sci U S A, 102, 1430-1435.

[13] Hong DP, Xiong W, Chang JY, \& Jiang C (2011) The role of the $\mathrm{C}$-terminus of human alpha-synuclein: Intradisulfide bonds between the $\mathrm{C}$-terminus and other regions 
stabilize non-fibrillar monomeric isomers. FEBS Lett, $\mathbf{5 8 5}$, 561-566.

[14] Uversky VN, Lee HJ, Li J, Fink AL, \& Lee SJ (2001) Stabilization of partially folded conformation during alphasynuclein oligomerization in both purified and cytosolic preparations. J Biol Chem, 276, 43495-43498.

[15] Ullman O, Fisher CK, \& Stultz CM (2011) Explaining the structural plasticity of alpha-synuclein. JAm Chem Soc, 133, 19536-19546.

[16] Chandra S, Chen X, Rizo J, Jahn R, \& Sudhof TC (2003) A broken alpha-helix in folded alpha-Synuclein. J Biol Chem, 278, 15313-15318.

[17] Ulmer TS, Bax A, Cole NB, \& Nussbaum RL (2005) Structure and dynamics of micelle-bound human alpha-synuclein. J Biol Chem, 280, 9595-9603.

[18] Jao CC, Hegde BG, Chen J, Haworth IS, \& Langen R (2008) Structure of membrane-bound alpha-synuclein from site-directed spin labeling and computational refinement. Proc Natl Acad Sci U S A, 105, 19666-19671.

[19] Bisaglia M, Mammi S, \& Bubacco L (2009) Structural insights on physiological functions and pathological effects of alpha-synuclein. FASEB J, 23, 329-340.

[20] Bartels T, Choi JG, \& Selkoe DJ (2011) alpha-Synuclein occurs physiologically as a helically folded tetramer that resists aggregation. Nature, 477, 107-110.

[21] Wang W, Perovic I, Chittuluru J, Kaganovich A, Nguyen LT, Liao J, Auclair JR, Johnson D, Landeru A, Simorellis AK, Ju S, Cookson MR, Asturias FJ, Agar JN, Webb BN, Kang C, Ringe D, Petsko GA, Pochapsky TC, \& Hoang QQ (2011) A soluble alpha-synuclein construct forms a dynamic tetramer. Proc Natl Acad Sci U S A, 108, 17797-17802.

[22] Fauvet B, Mbefo MK, Fares MB, Desobry C, Michael S, Ardah MT, Tsika E, Coune P, Prudent M, Lion N, Eliezer D, Moore DJ, Schneider B, Aebischer P, El-Agnaf OM, Masliah E, \& Lashuel HA (2012) alpha-Synuclein in central nervous system and from erythrocytes, mammalian cells, and Escherichia coli exists predominantly as disordered monomer. J Biol Chem, 287, 15345-15364.

[23] Bayer TA, Jakala P, Hartmann T, Egensperger R, Buslei R, Falkai P, \& Beyreuther K (1999) Neural expression profile of alpha-synuclein in developing human cortex. Neuroreport, 10, 2799-2803.

[24] Petersen K, Olesen OF, \& Mikkelsen JD (1999) Developmental expression of alpha-synuclein in rat hippocampus and cerebral cortex. Neuroscience, 91, 651-659.

[25] Raghavan R, Kruijff L, Sterrenburg MD, Rogers BB, Hladik CL \& White CL, 3rd (2004) Alpha-synuclein expression in the developing human brain. Pediatr Dev Pathol, 7, 506-516.

[26] Galvin JE, Schuck TM, Lee VM, \& Trojanowski JQ (2001) Differential expression and distribution of alpha-, beta-, and gamma-synuclein in the developing human substantia nigra. Exp Neurol, 168, 347-355.

[27] Li JY, Henning Jensen P, \& Dahlstrom A (2002) Differential localization of alpha-, beta- and gamma-synucleins in the rat CNS. Neuroscience, 113, 463-478.

[28] Zhong SC, Luo X, Chen XS, Cai QY, Liu J, Chen XH, \& Yao ZX (2010) Expression and subcellular location of alphasynuclein during mouse-embryonic development. Cell Mol Neurobiol, 30, 469-482.

[29] Hsu LJ, Mallory M, Xia Y, Veinbergs I, Hashimoto M, Yoshimoto M, Thal LJ, Saitoh T, \& Masliah E (1998) Expression pattern of synucleins (non-Abeta component of Alzheimer's disease amyloid precursor protein/alphasynuclein) during murine brain development. J Neurochem, 71, 338-344.
[30] Xuan Q, Xu SL, Lu DH, Yu S, Zhou M, Ueda K, Cui YQ, Zhang BY, \& Chan P (2011) Increased expression of alpha-synuclein in aged human brain associated with neuromelanin accumulation. J Neural Transm, 118, 1575-1583.

[31] Hirsch E, Graybiel AM, \& Agid YA (1988) Melanized dopaminergic neurons are differentially susceptible to degeneration in Parkinson's disease. Nature, 334, 345348 .

[32] Herrero MT, Hirsch EC, Kastner A, Ruberg M, Luquin MR, Laguna J, Javoy-Agid F, Obeso JA, \& Agid Y (1993) Does neuromelanin contribute to the vulnerability of catecholaminergic neurons in monkeys intoxicated with MPTP? Neuroscience, 56, 499-511.

[33] Chu Y, \& Kordower JH (2007) Age-associated increases of alpha-synuclein in monkeys and humans are associated with nigrostriatal dopamine depletion: Is this the target for Parkinson's disease? Neurobiol Dis, 25, 134-149.

[34] Malatynska E, Pinhasov A, Crooke J, Horowitz D, Brenneman DE, \& Ilyin SE (2006) Levels of mRNA coding for alpha-, beta-, and gamma-synuclein in the brains of newborn, juvenile, and adult rats. J Mol Neurosci, 29, 269-277.

[35] Mak SK, McCormack AL, Langston JW, Kordower JH, \& Di Monte DA (2009) Decreased alpha-synuclein expression in the aging mouse substantia nigra. Exp Neurol, 220, 359365 .

[36] Adamczyk A, Solecka J, \& Strosznajder JB (2005) Expression of alpha-synuclein in different brain parts of adult and aged rats. J Physiol Pharmacol, 56, 29-37.

[37] Collier TJ, Kanaan NM, \& Kordower JH (2011) Ageing as a primary risk factor for Parkinson's disease: Evidence from studies of non-human primates. Nat Rev Neurosci, 12, 359-366.

[38] Giasson BI, Duda JE, Murray IV, Chen Q, Souza JM, Hurtig HI, Ischiropoulos H, Trojanowski JQ, \& Lee VM (2000) Oxidative damage linked to neurodegeneration by selective alpha-synuclein nitration in synucleinopathy lesions. Science, 290, 985-989.

[39] Fujiwara H, Hasegawa M, Dohmae N, Kawashima A, Masliah E, Goldberg MS, Shen J, Takio K, \& Iwatsubo T (2002) alpha-Synuclein is phosphorylated in synucleinopathy lesions. Nat Cell Biol, 4, 160-164.

[40] McCormack AL, Mak SK, \& Di Monte DA (2012) Increased alpha-synuclein phosphorylation and nitration in the aging primate substantia nigra. Cell Death Dis, 3, e315.

[41] de Magalhaes JP, \& Sandberg A (2005) Cognitive aging as an extension of brain development: A model linking learning, brain plasticity, and neurodegeneration. Mech Ageing Dev, 126, 1026-1033

[42] Li W, Hoffman PN, Stirling W, Price DL, \& Lee MK (2004) Axonal transport of human alpha-synuclein slows with aging but is not affected by familial Parkinson's diseaselinked mutations. J Neurochem, 88, 401-410.

[43] Jensen PH, Li JY, Dahlstrom A, \& Dotti CG (1999) Axonal transport of synucleins is mediated by all rate components. Eur J Neurosci, 11, 3369-3376.

[44] Polymeropoulos MH, Lavedan C, Leroy E, Ide SE, Dehejia A, Dutra A, Pike B, Root H, Rubenstein J, Boyer R, Stenroos ES, Chandrasekharappa S, Athanassiadou A, Papapetropoulos T, Johnson WG, Lazzarini AM, Duvoisin RC, Di Iorio G, Golbe LI, \& Nussbaum RL (1997) Mutation in the alpha-synuclein gene identified in families with Parkinson's disease. Science, 276, 2045-2047.

[45] Kruger R, Kuhn W, Muller T, Woitalla D, Graeber M, Kose S, Przuntek H, Epplen JT, Schols L, \& Riess O (1998) 
Ala30Pro mutation in the gene encoding alpha-synuclein in Parkinson's disease. Nat Genet, 18, 106-108.

[46] Ibanez P, Bonnet AM, Debarges B, Lohmann E, Tison F, Pollak P, Agid Y, Durr A, \& Brice A (2004) Causal relation between alpha-synuclein gene duplication and familial Parkinson's disease. Lancet, 364, 1169-1171.

[47] Singleton AB, Farrer M, Johnson J, Singleton A, Hague S, Kachergus J, Hulihan M, Peuralinna T, Dutra A, Nussbaum R, Lincoln S, Crawley A, Hanson M, Maraganore D, Adler C, Cookson MR, Muenter M, Baptista M, Miller D, Blancato J, Hardy J, \& Gwinn-Hardy K (2003) alpha-Synuclein locus triplication causes Parkinson's disease. Science, 302, 841.

[48] Farrer M, Kachergus J, Forno L, Lincoln S, Wang DS, Hulihan M, Maraganore D, Gwinn-Hardy K, Wszolek Z, Dickson D, \& Langston JW (2004) Comparison of kindreds with parkinsonism and alpha-synuclein genomic multiplications. Ann Neurol, 55, 174-179.

[49] Spillantini MG, Schmidt ML, Lee VM, Trojanowski JQ, Jakes R, \& Goedert M (1997) Alpha-synuclein in Lewy bodies. Nature, 388, 839-840.

[50] Simon-Sanchez J, Schulte C, Bras JM, Sharma M, Gibbs JR, Berg D, Paisan-Ruiz C, Lichtner P, Scholz SW, Hernandez DG, Kruger R, Federoff M, Klein C, Goate A, Perlmutter J, Bonin M, Nalls MA, Illig T, Gieger C, Houlden H, Steffens M, Okun MS, Racette BA, Cookson MR, Foote KD, Fernandez HH, Traynor BJ, Schreiber S, Arepalli S, Zonozi R, Gwinn K, van der Brug M, Lopez G, Chanock SJ, Schatzkin A, Park Y, Hollenbeck A, Gao J, Huang X, Wood NW, Lorenz D, Deuschl G, Chen H, Riess O, Hardy JA, Singleton $\mathrm{AB}$, \& Gasser T (2009) Genome-wide association study reveals genetic risk underlying Parkinson's disease. Nat Genet, 41, 1308-1312.

[51] Breydo L, Wu JW, \& Uversky VN (2012) Alpha-synuclein misfolding and Parkinson's disease. Biochim Biophys Acta, 1822, 261-285.

[52] Ahmad B, Chen Y, \& Lapidus LJ (2012) Aggregation of alpha-synuclein is kinetically controlled by intramolecular diffusion. Proc Natl Acad Sci U S A, 109, 2336-2341.

[53] Ono K, Ikeda T, Takasaki J, \& Yamada M (2011) Familial Parkinson disease mutations influence alpha-synuclein assembly. Neurobiol Dis, 43, 715-724.

[54] Danzer KM, Haasen D, Karow AR, Moussaud S, Habeck M, Giese A, Kretzschmar H, Hengerer B, \& Kostka M (2007) Different species of alpha-synuclein oligomers induce calcium influx and seeding. $J$ Neurosci, 27, 92209232.

[55] Winner B, Jappelli R, Maji SK, Desplats PA, Boyer L, Aigner S, Hetzer C, Loher T, Vilar M, Campioni S, Tzitzilonis C, Soragni A, Jessberger S, Mira H, Consiglio A, Pham E, Masliah E, Gage FH, \& Riek R (2011) In vivo demonstration that alpha-synuclein oligomers are toxic. Proc Natl Acad Sci U S A, 108, 4194-4199.

[56] Caughey B, \& Lansbury PT (2003) Protofibrils, pores, fibrils, and neurodegeneration: Separating the responsible protein aggregates from the innocent bystanders. Annu Rev Neurosci, 26, 267-298.

[57] Volles MJ, \& Lansbury PT Jr. (2002) Vesicle permeabilization by protofibrillar alpha-synuclein is sensitive to Parkinson's disease-linked mutations and occurs by a porelike mechanism. Biochemistry, 41, 4595-4602.

[58] Harper JD, Lieber CM, \& Lansbury PT Jr. (1997) Atomic force microscopic imaging of seeded fibril formation and fibril branching by the Alzheimer's disease amyloid-beta protein. Chem Biol, 4, 951-959.
[59] Conway KA, Lee SJ, Rochet JC, Ding TT, Williamson RE, \& Lansbury PT Jr (2000) Acceleration of oligomerization, not fibrillization, is a shared property of both alpha-synuclein mutations linked to early-onset Parkinson's disease: Implications for pathogenesis and therapy. Proc Natl Acad Sci U S A, 97, 571-576.

[60] Li J, Uversky VN, \& Fink AL (2001) Effect of familial Parkinson's disease point mutations A30P and A53T on the structural properties, aggregation, and fibrillation of human alpha-synuclein. Biochemistry, 40, 11604-11613.

[61] Gertz HJ, Siegers A, \& Kuchinke J (1994) Stability of cell size and nucleolar size in Lewy body containing neurons of substantia nigra in Parkinson's disease. Brain Res, 637, 339-341.

[62] Tompkins MM, Basgall EJ, Zamrini E, \& Hill WD (1997) Apoptotic-like changes in Lewy-body-associated disorders and normal aging in substantia nigral neurons. Am J Pathol, 150, 119-131.

[63] Luk KC, Song C, O'Brien P, Stieber A, Branch JR, Brunden KR, Trojanowski JQ, \& Lee VM (2009) Exogenous alpha-synuclein fibrils seed the formation of Lewy body-like intracellular inclusions in cultured cells. Proc Natl Acad Sci U S A, 106, 20051-20056.

[64] Wood SJ, Wypych J, Steavenson S, Louis JC, Citron M, \& Biere AL (1999) alpha-synuclein fibrillogenesis is nucleation-dependent. Implications for the pathogenesis of Parkinson's disease. J Biol Chem, 274, 19509-19512.

[65] Volpicelli-Daley LA, Luk KC, Patel TP, Tanik SA, Riddle DM, Stieber A, Meaney DF, Trojanowski JQ, \& Lee VM (2011) Exogenous alpha-synuclein fibrils induce Lewy body pathology leading to synaptic dysfunction and neuron death. Neuron, 72, 57-71.

[66] Danzer KM, Krebs SK, Wolff M, Birk G, \& Hengerer B (2009) Seeding induced by alpha-synuclein oligomers provides evidence for spreading of alpha-synuclein pathology. J Neurochem, 111, 192-203.

[67] Hansen C, Angot E, Bergstrom AL, Steiner JA, Pieri L, Paul G, Outeiro TF, Melki R, Kallunki P, Fog K, Li JY, \& Brundin P (2011) alpha-Synuclein propagates from mouse brain to grafted dopaminergic neurons and seeds aggregation in cultured human cells. J Clin Invest, 121, 715-725.

[68] Olanow CW, \& Prusiner SB (2009) Is Parkinson's disease a prion disorder? Proc Natl Acad Sci U S A, 106, 1257112572.

[69] Kordower JH, Dodiya HB, Kordower AM, Terpstra B, Paumier K, Madhavan L, Sortwell C, Steece-Collier K, \& Collier TJ (2011) Transfer of host-derived alpha synuclein to grafted dopaminergic neurons in rat. Neurobiol Dis, $\mathbf{4 3}$, 552-557.

[70] Desplats P, Lee HJ, Bae EJ, Patrick C, Rockenstein E, Crews L, Spencer B, Masliah E, \& Lee SJ (2009) Inclusion formation and neuronal cell death through neuron-to-neuron transmission of alpha-synuclein. Proc Natl Acad Sci U S A, 106, 13010-13015.

[71] Luk KC, Kehm VM, Zhang B, O'Brien P, Trojanowski JQ, \& Lee VM (2012) Intracerebral inoculation of pathological alpha-synuclein initiates a rapidly progressive neurodegenerative alpha-synucleinopathy in mice. J Exp Med, 209, 975-986.

[72] Braak H, Del Tredici K, Rub U, de Vos RA, Jansen Steur EN, \& Braak E (2003) Staging of brain pathology related to sporadic Parkinson's disease. Neurobiol Aging, 24, 197-211.

[73] Eriksen JL, Dawson TM, Dickson DW, \& Petrucelli L (2003) Caught in the act: Alpha-synuclein is the culprit in Parkinson's disease. Neuron, 40, 453-456. 
[74] Khodr CE, Sapru MK, Pedapati J, Han Y, West NC, Kells AP, Bankiewicz KS, \& Bohn MC (2011) An alpha-synuclein AAV gene silencing vector ameliorates a behavioral deficit in a rat model of Parkinson's disease, but displays toxicity in dopamine neurons. Brain Res, 1395, 94-107.

[75] Gorbatyuk OS, Li S, Nash K, Gorbatyuk M, Lewin AS, Sullivan LF, Mandel RJ, Chen W, Meyers C, Manfredsson FP, \& Muzyczka N (2010) In vivo RNAi-mediated alphasynuclein silencing induces nigrostriatal degeneration. $\mathrm{Mol}$ Ther, 18, 1450-1457.

[76] McCormack AL, Mak SK, Henderson JM, Bumcrot D, Farrer MJ, \& Di Monte DA (2010) Alpha-synuclein suppression by targeted small interfering RNA in the primate substantia nigra. PLoS One, 5, e12122.

[77] Masliah E, Rockenstein E, Adame A, Alford M, Crews L, Hashimoto M, Seubert P, Lee M, Goldstein J, Chilcote T, Games D, \& Schenk D (2005) Effects of alpha-synuclein immunization in a mouse model of Parkinson's disease. Neuron, 46, 857-868.

[78] Li J, Zhu M, Rajamani S, Uversky VN, \& Fink AL (2004) Rifampicin inhibits alpha-synuclein fibrillation and disaggregates fibrils. Chem Biol, 11, 1513-1521.

[79] Fleming SM, \& Chesselet MF (2006) Behavioral phenotypes and pharmacology in genetic mouse models of Parkinsonism. Behav Pharmacol, 17, 383-391.

[80] Chesselet MF, \& Richter F (2011) Modelling of Parkinson's disease in mice. Lancet Neurol, 10, 1108-1118.

[81] Thiruchelvam MJ, Powers JM, Cory-Slechta DA, \& Richfield EK (2004) Risk factors for dopaminergic neuron loss in human alpha-synuclein transgenic mice. Eur J Neurosci, 19, 845-854.

[82] Wakamatsu M, Ishii A, Iwata S, Sakagami J, Ukai Y, Ono M, Kanbe D, Muramatsu S, Kobayashi K, Iwatsubo T, \& Yoshimoto M (2008) Selective loss of nigral dopamine neurons induced by overexpression of truncated human alpha-synuclein in mice. Neurobiol Aging, 29, 574585.

[83] Lin X, Parisiadou L, Sgobio C, Liu G, Yu J, Sun L, Shim H, Gu XL, Luo J, Long CX, Ding J, Mateo Y, Sullivan PH, Wu LG, Goldstein DS, Lovinger D, \& Cai H (2012) Conditional expression of Parkinson's disease-related mutant alpha-Synuclein in the midbrain dopaminergic neurons causes progressive neurodegeneration and degradation of transcription factor nuclear receptor related 1. J Neurosci, 32, 9248-9264.

[84] Chu Y, Le W, Kompoliti K, Jankovic J, Mufson EJ, \& Kordower JH (2006) Nurr1 in Parkinson's disease and related disorders. J Comp Neurol, 494, 495-514.

[85] Le WD, Xu P, Jankovic J, Jiang H, Appel SH, Smith RG, \& Vassilatis DK (2003) Mutations in NR4A2 associated with familial Parkinson disease. Nat Genet, 33, 85-89.

[86] Galleguillos D, Fuentealba JA, Gomez LM, Saver M, Gomez A, Nash K, Burger C, Gysling K, \& Andres ME (2010) Nurr1 regulates RET expression in dopamine neurons of adult rat midbrain. J Neurochem, 114, 1158-1167.

[87] Decressac M, Mattsson B, Lundblad M, Weikop P, \& Bjorklund A (2012) Progressive neurodegenerative and behavioural changes induced by AAV-mediated overexpression of alpha-synuclein in midbrain dopamine neurons. Neurobiol Dis, 45, 939-953.

[88] Decressac M, Ulusoy A, Mattsson B, Georgievska B, Romero-Ramos M, Kirik D, \& Bjorklund A (2011) GDNF fails to exert neuroprotection in a rat alphasynuclein model of Parkinson's disease. Brain, 134, 23022311.
[89] Hoffer BJ, Hoffman A, Bowenkamp K, Huettl P, Hudson J, Martin D, Lin LF, \& Gerhardt GA (1994) Glial cell line-derived neurotrophic factor reverses toxin-induced injury to midbrain dopaminergic neurons in vivo. Neurosci Lett, 182, 107-111.

[90] Mandel RJ, Spratt SK, Snyder RO, \& Leff SE (1997) Midbrain injection of recombinant adeno-associated virus encoding rat glial cell line-derived neurotrophic factor protects nigral neurons in a progressive 6-hydroxydopamineinduced degeneration model of Parkinson's disease in rats. Proc Natl Acad Sci U S A, 94, 14083-14088.

[91] Tomac A, Lindqvist E, Lin LF, Ogren SO, Young D, Hoffer BJ, \& Olson L (1995) Protection and repair of the nigrostriatal dopaminergic system by GDNF in vivo. Nature, $\mathbf{3 7 3}$, 335-339.

[92] Kordower JH, Emborg ME, Bloch J, Ma SY, Chu Y, Leventhal L, McBride J, Chen EY, Palfi S, Roitberg BZ, Brown WD, Holden JE, Pyzalski R, Taylor MD, Carvey P, Ling Z, Trono D, Hantraye P, Deglon N, \& Aebischer P (2000) Neurodegeneration prevented by lentiviral vector delivery of GDNF in primate models of Parkinson's disease. Science, 290, 767-773.

[93] Chung CY, Koprich JB, Siddiqi H, \& Isacson O (2009) Dynamic changes in presynaptic and axonal transport proteins combined with striatal neuroinflammation precede dopaminergic neuronal loss in a rat model of AAV alphasynucleinopathy. J Neurosci, 29, 3365-3373.

[94] Kirik D, Rosenblad C, Burger C, Lundberg C, Johansen TE, Muzyczka N, Mandel RJ, \& Bjorklund A (2002) Parkinsonlike neurodegeneration induced by targeted overexpression of alpha-synuclein in the nigrostriatal system. J Neurosci, 22, 2780-2791.

[95] Ulusoy A, Bjorklund T, Buck K, \& Kirik D (2012) Dysregulated dopamine storage increases the vulnerability to alpha-synuclein in nigral neurons. Neurobiol Dis, 47, 367377.

[96] Feany MB, \& Bender WW (2000) A Drosophila model of Parkinson's disease. Nature, 404, 394-398.

[97] Karpinar DP, Balija MB, Kugler S, Opazo F, Rezaei-Ghaleh N, Wender N, Kim HY, Taschenberger G, Falkenburger BH, Heise H, Kumar A, Riedel D, Fichtner L, Voigt A, Braus GH, Giller K, Becker S, Herzig A, Baldus M, Jackle H, Eimer S, Schulz JB, Griesinger C, \& Zweckstetter M (2009) Pre-fibrillar alpha-synuclein variants with impaired beta-structure increase neurotoxicity in Parkinson's disease models. EMBO J, 28, 3256-3268.

[98] Woods WS, Boettcher JM, Zhou DH, Kloepper KD, Hartman KL, Ladror DT, Qi Z, Rienstra CM, \& George JM (2007) Conformation-specific binding of alpha-synuclein to novel protein partners detected by phage display and NMR spectroscopy. J Biol Chem, 282, 34555-34567.

[99] Burre J, Sharma M, Tsetsenis T, Buchman V, Etherton MR, \& Sudhof TC (2010) Alpha-synuclein promotes SNAREcomplex assembly in vivo and in vitro. Science, 329, 16631667.

[100] Chandra S, Gallardo G, Fernandez-Chacon R, Schluter OM, \& Sudhof TC (2005) Alpha-synuclein cooperates with CSPalpha in preventing neurodegeneration. Cell, 123, 383396.

[101] Cabin DE, Shimazu K, Murphy D, Cole NB, Gottschalk W, McIlwain KL, Orrison B, Chen A, Ellis CE, Paylor R, Lu B, \& Nussbaum RL (2002) Synaptic vesicle depletion correlates with attenuated synaptic responses to prolonged repetitive stimulation in mice lacking alpha-synuclein. $J$ Neurosci, 22, 8797-8807. 
[102] Scott D, \& Roy S (2012) alpha-Synuclein inhibits intersynaptic vesicle mobility and maintains recycling-pool homeostasis. J Neurosci, 32, 10129-10135.

[103] Cooper AA, Gitler AD, Cashikar A, Haynes CM, Hill KJ, Bhullar B, Liu K, Xu K, Strathearn KE, Liu F, Cao S, Caldwell KA, Caldwell GA, Marsischky G, Kolodner RD, Labaer J, Rochet JC, Bonini NM, \& Lindquist S (2006) Alpha-synuclein blocks ER-Golgi traffic and Rab1 rescues neuron loss in Parkinson's models. Science, 313, 324328.

[104] Gitler AD, Bevis BJ, Shorter J, Strathearn KE, Hamamichi S, Su LJ, Caldwell KA, Caldwell GA, Rochet JC, McCaffery JM, Barlowe C, \& Lindquist S (2008) The Parkinson's disease protein alpha-synuclein disrupts cellular Rab homeostasis. Proc Natl Acad Sci U S A, 105, 145-150.

[105] Soper JH, Roy S, Stieber A, Lee E, Wilson RB, Trojanowski JQ, Burd CG, \& Lee VM (2008) Alpha-synuclein-induced aggregation of cytoplasmic vesicles in Saccharomyces cerevisiae. Mol Biol Cell, 19, 1093-1103.

[106] Thayanidhi N, Helm JR, Nycz DC, Bentley M, Liang Y, \& Hay JC (2010) Alpha-synuclein delays endoplasmic reticulum (ER)-to-Golgi transport in mammalian cells by antagonizing ER/Golgi SNAREs. Mol Biol Cell, 21, 18501863.

[107] Larsen KE, Schmitz Y, Troyer MD, Mosharov E, Dietrich P, Quazi AZ, Savalle M, Nemani V, Chaudhry FA, Edwards RH, Stefanis L, \& Sulzer D (2006) Alphasynuclein overexpression in PC12 and chromaffin cells impairs catecholamine release by interfering with a late step in exocytosis. J Neurosci, 26, 11915-11922.

[108] Gaugler MN, Genc O, Bobela W, Mohanna S, Ardah MT, El-Agnaf OM, Cantoni M, Bensadoun JC, Schneggenburger R, Knott GW, Aebischer P, \& Schneider BL (2012) Nigrostriatal overabundance of alpha-synuclein leads to decreased vesicle density and deficits in dopamine release that correlate with reduced motor activity. Acta Neuropathol, $\mathbf{1 2 3}$ 653-669.

[109] Lundblad M, Decressac M, Mattsson B, \& Bjorklund A (2012) Impaired neurotransmission caused by overexpression of alpha-synuclein in nigral dopamine neurons. Proc Natl Acad Sci U S A, 109, 3213-3219.

[110] Chadchankar H, Ihalainen J, Tanila H, \& Yavich L (2011) Decreased reuptake of dopamine in the dorsal striatum in the absence of alpha-synuclein. Brain Res, 1382, 37-44.

[111] Liu S, Ninan I, Antonova I, Battaglia F, Trinchese F, Narasanna A, Kolodilov N, Dauer W, Hawkins RD, \& Arancio O (2004) alpha-Synuclein produces a long-lasting increase in neurotransmitter release. EMBO J, 23, 45064516

[112] Shavali S, Brown-Borg HM, Ebadi M, \& Porter J (2008) Mitochondrial localization of alpha-synuclein protein in alpha-synuclein overexpressing cells. Neurosci Lett, $\mathbf{4 3 9}$, 125-128.

[113] Cole NB, Dieuliis D, Leo P, Mitchell DC, \& Nussbaum RL (2008) Mitochondrial translocation of alpha-synuclein is promoted by intracellular acidification. Exp Cell Res, 314, 2076-2089.

[114] Devi L, Raghavendran V, Prabhu BM, Avadhani NG, \& Anandatheerthavarada HK (2008) Mitochondrial import and accumulation of alpha-synuclein impair complex I in human dopaminergic neuronal cultures and Parkinson disease brain. J Biol Chem, 283, 9089-9100.

[115] Li WW, Yang R, Guo JC, Ren HM, Zha XL, Cheng JS, \& Cai DF (2007) Localization of alpha-synuclein to mitochondria within midbrain of mice. Neuroreport, 18, 1543-1546.
[116] Kamp F, Exner N, Lutz AK, Wender N, Hegermann J, Brunner B, Nuscher B, Bartels T, Giese A, Beyer K, Eimer S, Winklhofer KF \& Haass C (2010) Inhibition of mitochondrial fusion by alpha-synuclein is rescued by PINK1, Parkin and DJ-1. EMBO J, 29, 3571-3589.

[117] Nakamura K, Nemani VM, Azarbal F, Skibinski G, Levy JM, Egami K, Munishkina L, Zhang J, Gardner B, Wakabayashi J, Sesaki H, Cheng Y, Finkbeiner S, Nussbaum RL, Masliah E, \& Edwards RH (2011) Direct membrane association drives mitochondrial fission by the Parkinson disease-associated protein alpha-synuclein. J Biol Chem, 286, 20710-20726.

[118] Cali T, Ottolini D, Negro A, \& Brini M (2012) alphaSynuclein controls mitochondrial calcium homeostasis by enhancing endoplasmic reticulum-mitochondria interactions. J Biol Chem, 287, 17914-17929.

[119] Federico A, Cardaioli E, Da Pozzo P, Formichi P, Gallus GN, Radi E (2012) Mitochondria, oxidative stress and neurodegeneration. J Neurol Sci, 322, 254-262.

[120] Jin J, Li GJ, Davis J, Zhu D, Wang Y, Pan C, \& Zhang J (2007) Identification of novel proteins associated with both alpha-synuclein and DJ-1. Mol Cell Proteomics, 6, 845-859.

[121] Burbulla LF, \& Kruger R (2011) Converging environmental and genetic pathways in the pathogenesis of Parkinson's disease. J Neurol Sci, 306, 1-8.

[122] Szabadkai G, Bianchi K, Varnai P, De Stefani D, Wieckowski MR, Cavagna D, Nagy AI, Balla T, \& Rizzuto $\mathrm{R}$ (2006) Chaperone-mediated coupling of endoplasmic reticulum and mitochondrial $\mathrm{Ca} 2+$ channels. J Cell Biol, 175, 901-911.

[123] Martinez J, Moeller I, Erdjument-Bromage H, Tempst P, \& Lauring B (2003) Parkinson's disease-associated alphasynuclein is a calmodulin substrate. J Biol Chem, 278, 17379-17387.

[124] Reznichenko L, Cheng Q, Nizar K, Gratiy SL, Saisan PA, Rockenstein EM, Gonzalez T, Patrick C, Spencer B, Desplats P, Dale AM, Devor A, \& Masliah E (2012) In vivo alterations in calcium buffering capacity in transgenic mouse model of synucleinopathy. J Neurosci, 32, 99929998.

[125] Parihar MS, Parihar A, Fujita M, Hashimoto M, \& Ghafourifar P (2008) Mitochondrial association of alpha-synuclein causes oxidative stress. Cell Mol Life Sci, 65, 12721284.

[126] Hettiarachchi NT, Parker A, Dallas ML, Pennington K, Hung CC, Pearson HA, Boyle JP, Robinson P, \& Peers C (2009) alpha-Synuclein modulation of $\mathrm{Ca} 2+$ signaling in human neuroblastoma (SH-SY5Y) cells. J Neurochem, 111, 1192-1201.

[127] Oaks AW, \& Sidhu A (2011) Synuclein modulation of monoamine transporters. FEBS Lett, 585, 1001-1006.

[128] Lee FJ, Liu F, Pristupa ZB, \& Niznik HB (2001) Direct binding and functional coupling of alpha-synuclein to the dopamine transporters accelerate dopamine-induced apoptosis. FASEB J, 15, 916-926.

[129] Wersinger C, Prou D, Vernier P, \& Sidhu A (2003) Modulation of dopamine transporter function by alpha-synuclein is altered by impairment of cell adhesion and by induction of oxidative stress. FASEB J, 17, 2151-2153.

[130] Fountaine TM, Venda LL, Warrick N, Christian HC, Brundin P, Channon KM, \& Wade-Martins R (2008) The effect of alpha-synuclein knockdown on MPP+ toxicity in models of human neurons. Eur J Neurosci, 28, 2459-2473.

[131] Fountaine TM, \& Wade-Martins R (2007) RNA interference-mediated knockdown of alpha-synuclein 
protects human dopaminergic neuroblastoma cells from $\mathrm{MPP}(+)$ toxicity and reduces dopamine transport. J Neurosci Res, 85, 351-363.

[132] Wersinger C, \& Sidhu A (2003) Attenuation of dopamine transporter activity by alpha-synuclein. Neurosci Lett, $\mathbf{3 4 0}$, 189-192.

[133] Wersinger C, \& Sidhu A (2005) Disruption of the interaction of alpha-synuclein with microtubules enhances cell surface recruitment of the dopamine transporter. Biochemistry, $\mathbf{4 4 ,}$ 13612-13624.

[134] Dauer W, Kholodilov N, Vila M, Trillat AC, Goodchild R, Larsen KE, Staal R, Tieu K, Schmitz Y, Yuan CA, Rocha M, Jackson-Lewis V, Hersch S, Sulzer D, Przedborski S, Burke R, \& Hen R (2002) Resistance of alpha -synuclein null mice to the parkinsonian neurotoxin MPTP. Proc Natl Acad Sci U S A, 99, 14524-14529.

[135] Eriksen J, Jorgensen TN, \& Gether U (2010) Regulation of dopamine transporter function by protein-protein interactions: New discoveries and methodological challenges. J Neurochem, 113, 27-41.

[136] Cragg SJ, \& Rice ME (2004) DAncing past the DAT at a DA synapse. Trends Neurosci, 27, 270-277.

[137] Yu S, Zuo X, Li Y, Zhang C, Zhou M, Zhang YA, Ueda K, \& Chan P (2004) Inhibition of tyrosine hydroxylase expression in alpha-synuclein-transfected dopaminergic neuronal cells. Neurosci Lett, 367, 34-39.

[138] Perez RG, Waymire JC, Lin E, Liu JJ, Guo F, \& Zigmond MJ (2002) A role for alpha-synuclein in the regulation of dopamine biosynthesis. J Neurosci, 22, 3090-3099.

[139] Peng X, Tehranian R, Dietrich P, Stefanis L, \& Perez RG (2005) Alpha-synuclein activation of protein phosphatase $2 \mathrm{~A}$ reduces tyrosine hydroxylase phosphorylation in dopaminergic cells. J Cell Sci, 118, 3523-3530.

[140] Tehranian R, Montoya SE, Van Laar AD, Hastings TG, \& Perez RG (2006) Alpha-synuclein inhibits aromatic amino acid decarboxylase activity in dopaminergic cells. $\mathrm{J} \mathrm{Neu}$ rochem, 99, 1188-1196.

[141] McFarland MA, Ellis CE, Markey SP, \& Nussbaum RL (2008) Proteomics analysis identifies phosphorylationdependent alpha-synuclein protein interactions. Mol Cell Proteomics, 7, 2123-2137.

[142] Pennington K, Peng J, Hung CC, Banks RE, \& Robinson PA (2010) Differential effects of wild-type and A53T mutant isoform of alpha-synuclein on the mitochondrial proteome of differentiated SH-SY5Y cells. J Proteome Res, 9, 23902401.

[143] Ostrerova N, Petrucelli L, Farrer M, Mehta N, Choi P, Hardy J, \& Wolozin B (1999) alpha-Synuclein shares physical and functional homology with 14-3-3 proteins. J Neurosci, 19, 5782-5791.

[144] Martin I, Dawson VL, \& Dawson TM (2011) Recent advances in the genetics of Parkinson's disease. Annu Rev Genomics Hum Genet, 12, 301-325.

[145] Zhou W, Zhu M, Wilson MA, Petsko GA, \& Fink AL (2006) The oxidation state of DJ-1 regulates its chaperone activity toward alpha-synuclein. J Mol Biol, 356, 1036-1048.

[146] Shendelman S, Jonason A, Martinat C, Leete T, \& Abeliovich A (2004) DJ-1 is a redox-dependent molecular chaperone that inhibits alpha-synuclein aggregate formation. PLoS Biol, 2, e362.

[147] Zhou W, \& Freed CR (2005) DJ-1 up-regulates glutathione synthesis during oxidative stress and inhibits A53T alphasynuclein toxicity. J Biol Chem, 280, 43150-43158.

[148] Batelli S, Albani D, Rametta R, Polito L, Prato F, Pesaresi M, Negro A, \& Forloni G (2008) DJ-1 modulates alpha- synuclein aggregation state in a cellular model of oxidative stress: Relevance for Parkinson's disease and involvement of HSP70. PLoS One, 3, e1884.

[149] Siddiqui A, Chinta SJ, Mallajosyula JK, Rajagopolan S, Hanson I, Rane A, Melov S, \& Andersen JK (2012) Selective binding of nuclear alpha-synuclein to the PGClalpha promoter under conditions of oxidative stress may contribute to losses in mitochondrial function: Implications for Parkinson's disease. Free Radic Biol Med, 53, 993-1003.

[150] Goers J, Manning-Bog AB, McCormack AL, Millett IS, Doniach S, Di Monte DA, Uversky VN, \& Fink AL (2003) Nuclear localization of alpha-synuclein and its interaction with histones. Biochemistry, 42, 8465-8471.

[151] Kontopoulos E, Parvin JD, \& Feany MB (2006) Alphasynuclein acts in the nucleus to inhibit histone acetylation and promote neurotoxicity. Hum Mol Genet, 15, 30123023.

[152] Morfini GA, Burns M, Binder LI, Kanaan NM, LaPointe N, Bosco DA, Brown RH Jr, Brown H, Tiwari A, Hayward L, Edgar J, Nave KA, Garberrn J, Atagi Y, Song Y, Pigino G, \& Brady ST (2009) Axonal transport defects in neurodegenerative diseases. J Neurosci, 29, 1277612786.

[153] Fortin DL, Troyer MD, Nakamura K, Kubo S, Anthony MD, \& Edwards RH (2004) Lipid rafts mediate the synaptic localization of alpha-synuclein. J Neurosci, 24, 6715-6723.

[154] Gorbatyuk OS, Li S, Nha Nguyen F, Manfredsson FP, Kondrikova G, Sullivan LF, Meyers C, Chen W, Mandel RJ, \& Muzyczka N (2010) alpha-Synuclein expression in rat substantia nigra suppresses phospholipase D2 toxicity and nigral neurodegeneration. Mol Ther, 18, 1758-1768.

[155] Payton JE, Perrin RJ, Woods WS, \& George JM (2004) Structural determinants of PLD2 inhibition by alphasynuclein. J Mol Biol, 337, 1001-1009.

[156] Jenco JM, Rawlingson A, Daniels B, \& Morris AJ (1998) Regulation of phospholipase D2: Selective inhibition of mammalian phospholipase D isoenzymes by alpha- and beta-synucleins. Biochemistry, 37, 4901-4909.

[157] Abeliovich A, Schmitz Y, Farinas I, Choi-Lundberg D, Ho WH, Castillo PE, Shinsky N, Verdugo JM, Armanini M, Ryan A, Hynes M, Phillips H, Sulzer D, \& Rosenthal A (2000) Mice lacking alpha-synuclein display functional deficits in the nigrostriatal dopamine system. Neuron, $\mathbf{2 5}$, 239-252.

[158] Robertson DC, Schmidt O, Ninkina N, Jones PA, Sharkey J, \& Buchman VL (2004) Developmental loss and resistance to MPTP toxicity of dopaminergic neurones in substantia nigra pars compacta of gamma-synuclein, alpha-synuclein and double alpha/gamma-synuclein null mutant mice. $\mathrm{J} \mathrm{Neu}$ rochem, 89, 1126-1136.

[159] Schluter OM, Fornai F, Alessandri MG, Takamori S, Geppert M, Jahn R, \& Sudhof TC (2003) Role of alphasynuclein in 1-methyl-4-phenyl-1,2,3,6-tetrahydropyridineinduced parkinsonism in mice. Neuroscience, 118, 9851002 .

[160] Morice E, Denis C, Giros B, \& Nosten-Bertrand M (2004) Phenotypic expression of the targeted null-mutation in the dopamine transporter gene varies as a function of the genetic background. Eur J Neurosci, 20, 120-126.

[161] Al-Wandi A, Ninkina N, Millership S, Williamson SJ, Jones PA, \& Buchman VL (2010) Absence of alpha-synuclein affects dopamine metabolism and synaptic markers in the striatum of aging mice. Neurobiol Aging, 31, 796-804.

[162] Drolet RE, Behrouz B, Lookingland KJ, \& Goudreau JL (2004) Mice lacking alpha-synuclein have an attenuated loss 
of striatal dopamine following prolonged chronic MPTP administration. Neurotoxicology, 25, 761-769.

[163] Kuhn M, Haebig K, Bonin M, Ninkina N, Buchman VL, Poths S, \& Riess O (2007) Whole genome expression analyses of single- and double-knock-out mice implicate partially overlapping functions of alpha- and gamma-synuclein. $\mathrm{Neu}$ rogenetics, $\mathbf{8}, 71-81$.

[164] Habig K, Walter M, Stappert H, Riess O, \& Bonin M (2009) Microarray expression analysis of human dopaminergic neuroblastoma cells after RNA interference of SNCA-a key player in the pathogenesis of Parkinson's disease. Brain Res, 1256, 19-33.

[165] Chandra S, Fornai F, Kwon HB, Yazdani U, Atasoy D, Liu X, Hammer RE, Battaglia G, German DC, Castillo PE, \& Sudhof TC (2004) Double-knockout mice for alpha- and beta-synucleins: Effect on synaptic functions. Proc Natl Acad Sci U S A, 101, 14966-14971.

[166] Anwar S, Peters O, Millership S, Ninkina N, Doig N, Connor-Robson N, Threlfell S, Kooner G, Deacon RM, Bannerman DM, Bolam JP, Chandra SS, Cragg SJ, Wade-Martins R, \& Buchman VL (2011) Functional alterations to the nigrostriatal system in mice lacking all three members of the synuclein family. J Neurosci, 31, 7264-7274.

[167] Greten-Harrison B, Polydoro M, Morimoto-Tomita M, Diao L, Williams AM, Nie EH, Makani S, Tian N, Castillo PE, Buchman VL, \& Chandra SS (2010) alphabetagammaSynuclein triple knockout mice reveal age-dependent neuronal dysfunction. Proc Natl Acad Sci USA, 107, 1957319578.

[168] Perez RG, Hastings TG (2004) Could a loss of alphasynuclein function put dopaminergic neurons at risk? $J$ Neurochem, 89, 1318-1324.

[169] Cookson MR (2006) Hero versus antihero: The multiple roles of alpha-synuclein in neurodegeneration. Exp Neurol, 199, 238-242.

[170] Zuccato C, Valenza M, \& Cattaneo E (2010) Molecular mechanisms and potential therapeutical targets in Huntington's disease. Physiol Rev, 90, 905-981.

[171] Seo JH, Rah JC, Choi SH, Shin JK, Min K, Kim HS, Park CH, Kim S, Kim EM, Lee SH, Lee S, Suh SW, \& Suh YH (2002) Alpha-synuclein regulates neuronal survival via Bcl2 family expression and PI3/Akt kinase pathway. FASEB J, 16, 1826-1828.
[172] Alves Da Costa C, Paitel E, Vincent B, \& Checler F (2002) Alpha-synuclein lowers p53-dependent apoptotic response of neuronal cells. Abolishment by 6-hydroxydopamine and implication for Parkinson's disease. J Biol Chem, 277, 50980-50984.

[173] Jensen PJ, Alter BJ, \& O’Malley KL (2003) Alphasynuclein protects naive but not dbcAMP-treated dopaminergic cell types from 1-methyl-4-phenylpyridinium toxicity. J Neurochem, 86, 196-209.

[174] Fernandez-Chacon R, Wolfel M, Nishimune H, Tabares L, Schmitz F, Castellano-Munoz M, Rosenmund C, Montesinos ML, Sanes JR, Schneggenburger R, \& Sudhof TC (2004) The synaptic vesicle protein CSP alpha prevents presynaptic degeneration. Neuron, 42, 237-251.

[175] Quilty MC, King AE, Gai WP, Pountney DL, West AK, Vickers JC, \& Dickson TC (2006) Alpha-synuclein is upregulated in neurones in response to chronic oxidative stress and is associated with neuroprotection. Exp Neurol, 199, 249-256.

[176] Jin H, Kanthasamy A, Ghosh A, Yang Y, Anantharam V, \& Kanthasamy AG (2011) alpha-Synuclein negatively regulates protein kinase Cdelta expression to suppress apoptosis in dopaminergic neurons by reducing p300 histone acetyltransferase activity. J Neurosci, 31, 2035-2051.

[177] Perez-Sanchez F, Milan M, Buendia P, Cano-Jaimez M, Ambrosio S, Rosenthal A, \& Farinas I (2010) Prosurvival effect of human wild-type alpha-synuclein on MPTP-induced toxicity to central but not peripheral catecholaminergic neurons isolated from transgenic mice. Neuroscience, 167, 261-276.

[178] Hashimoto M, Hsu LJ, Rockenstein E, Takenouchi T, Mallory M, \& Masliah E (2002) alpha-Synuclein protects against oxidative stress via inactivation of the c-Jun $\mathrm{N}$ terminal kinase stress-signaling pathway in neuronal cells. J Biol Chem, 277, 11465-11472.

[179] Kirik D, Annett LE, Burger C, Muzyczka N, Mandel RJ, \& Bjorklund A (2003) Nigrostriatal alpha-synucleinopathy induced by viral vector-mediated overexpression of human alpha-synuclein: A new primate model of Parkinson's disease. Proc Natl Acad Sci U S A, 100, 2884-2889. 